\title{
A Faunistic Study on Cheilostomatous Bryozoans from the Shoreline of South Korea, with Two New Species
}

\author{
Ji Eun $\mathrm{Seo}^{1, *}$ and Bum Sik Min² \\ 'Department of Rehabilitation Welfare, College of Health Welfare, Woosuk University, \\ Jeonbuk 565-701, Korea \\ ${ }^{2}$ Department of Biology, Graduate School of Woosuk University, Jeonbuk 565-701, Korea
}

\begin{abstract}
Seventy-one species of the order cheilostomatous bryozoans are reported from coasts of southern Korea. Among them, Callpora inaviculata and Integripelta meta are described as new species and the following eight species are reported as new records of Korea: Membranipora irregulata, Tegella crenulata, Beania regularis, Celleporaria brunnea, Exochella tricuspis, Calyptotheca parcimunita, Microporella borealis, Celleporina rostellata.
\end{abstract}

Key words: taxonomy, fauna, new species, Cheilostomata, Bryozoa, South Korea

\section{INTRODUCTION}

Cheilostomata is the largest and most diverse order of the phylum Bryozoa. Since Scanning Electron Microscope has dramatically been used for its taxonomic work, new species are being added in the fauna of bryozoans continually as well as many species are currently being revised. However, quite a few species are still uncertain in their taxonomic status, and thus needed to be revised.

Since Okada (1923) reported 49 species from the Strait of Korea, the faunistic studies of the Korean cheilostomatous bryozoans have been done mainly by Seo. Seo (2005) reviewed 102 species of cheilostomatous bryozoans known until that time. Since this work, Seo and Gong (2006) recorded Buffonellaria acutirostris as a new species and Thalamoporella sibogae Soule, Soule and Chaney, 1992 and Schizomavella acuta Osburn, 1952 both as new records of Korea. However, more new species and new records are expected to be found from Korea.

This paper deals with the descriptions of two new species and eight new records of Cheilostomata from South Korea. New collection data for previously recorded species are also reported.

\section{MATERIALS AND METHODS}

Seventy one species of cheilostomatous bryozoans were collected from 51 sites of South Korea during the period

*To whom correspondence should be addressed

Tel: 82-63-290-1516, Fax: 82-63-290-1516

E-mail: jeseo@woosuk.ac.kr from 1970 to 2007 (Fig. 1). Collecting specimens was done from various habitats such as rocky bottom, shells and other substrata in intertidal zone, fishing nets, subtidal zone, test panels for ecological research, and aquaculture facilities, etc. For scanning electron microscopy, the materials were bleached, and then coated with ion sputter coater and examined with a Scanning Electon Microscope (SEM). Holotypes will be deposited in the National Institute of Biological Resources, Korea and paratypes are kept in the collection of the corresponding author.

\section{SYSTEMATIC ACCOUNTS}

Phylum Bryozoa Ehrenberg, 1831

Class Gymnolaemata Allman, 1856

Order Cheilostomata Busk, 1852

Suborder Inovicellata Jullien, 1888

Superfamily Aeteoidea Smitt, 1867

Family Aeteidae Smitt, 1867

Genus Aetea Smitt, 1867

Aetea anguina (Linné, 1758)

Material examined. Sangchujado Island, 16 Jul. 1987 (J.W. Lee) by SCUBA diving from $15 \mathrm{~m}$ in depth.

Substratum. Other bryozoan.

Distribution. Cosmopolitan. In Korea, it is found from the South Sea and Jeju-do.

Suborder Malacostega Levinsen, 1909

Superfamily Membraniporoidea Busk, 1854

Family Membraniporidae Busk, 1854 


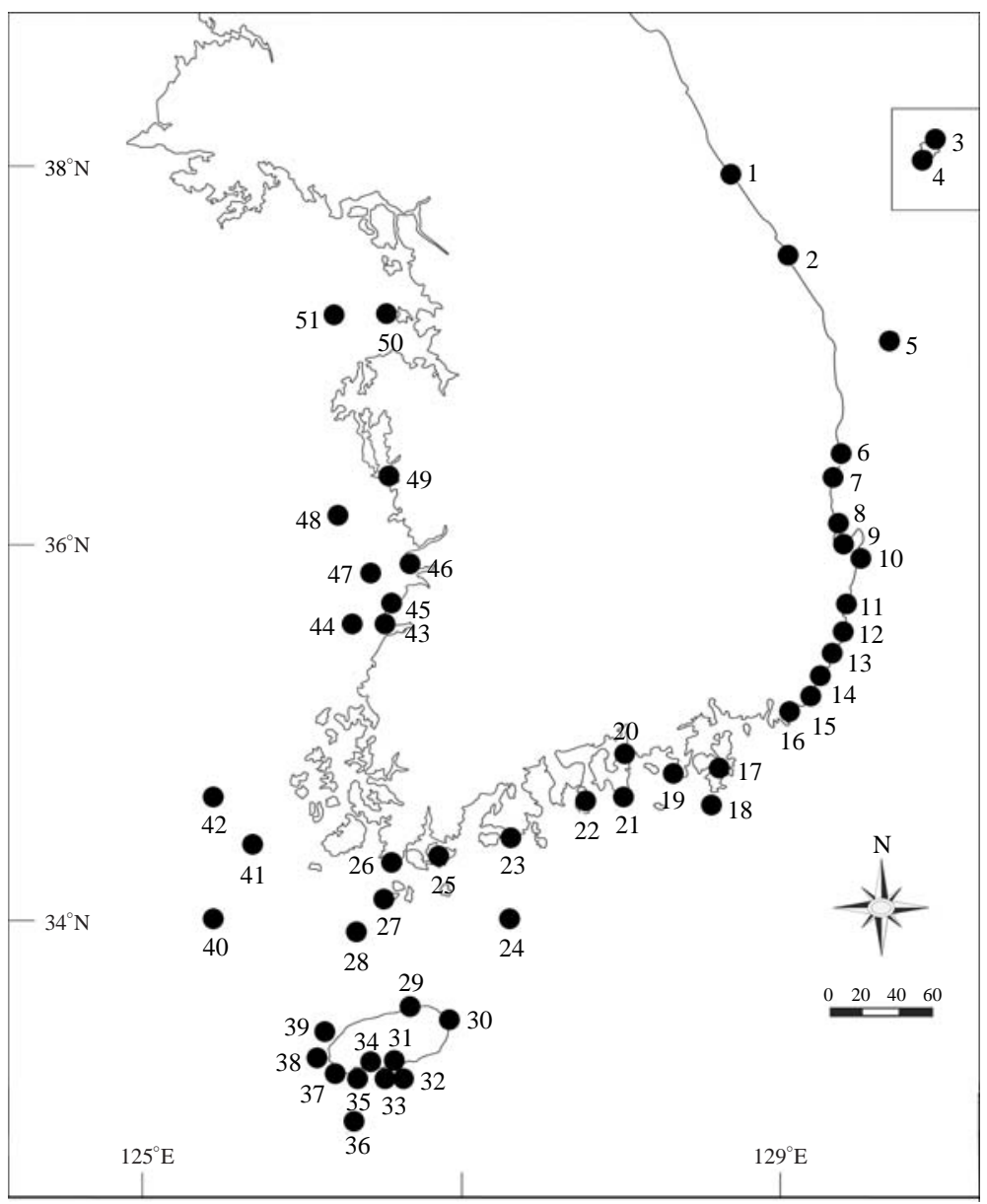

Fig. 1. A map showing the collection localities in South Korea. 1, Namae Port; 2, Yonguimeori, Daejin; 3, Wadal-ri, Ulreungdo Island; 4, Tonggumi, Ulreungdo Island; 5, Wangdolcho, Uljin; 6, Changpo 2-ri, Gyeongjeong; 7, Geondal, Yeongdeok; 8, Sobongdae, Yangpo; 9, Masan and 1-ri, Balsan; 10, Samjeong, Guryongpo; 11, Chuksa and Gampo Port, Gampo; 12, Wolseong; 13, Ulgi light house; 14, Dangsa, Ulsan; 15, Seuldo Island, Bangeojin; 16, Mipo, Busan; 17, Daepo, Gabae, Gudo Island, Gujora, Hangmakjung, Heungnam, Hyangmyeongchon, Janghang, Susan and Yunpo, Geojedo Island; 18, Dongseom Island, Maemuldo Island; 19, Bongdo Island, Budo Island, Chukdo Island, Daejangdudo Island, Daemangjado Island, Godo Island, Hahangdo Island, Hangdo Island, Hodo Island, Hwado Island, Ido Island, Jangdo Island, Jukdo Island, Junghangdo Island, Jungpyeon in Gollido Island, Pildo Island, Saryangdo Island, Taedo Island, Tongyeong Marine Ranch, Uldo Island, Yudo Island and Yujado Island, Tongyeong; 20, Adudo Island, Bakdeungdo Island, Gaeseom Island, Hyanggido Island, Keungaeseom Island, Mokdo Island, Samcheonpo and Solseom Island, Sacheon; 21, Mijo-ri and Sangju-ri, Namhaedo Island; 22, Ohak-ri, Geumodo Island; 23, Jijukdo Island; 24, Baekdo Island and Husuwolsan light house in Seodo Island, Geomundo Island; 25, Cheokdo Island and Daechilgido Island, Wando Island; 26, Jeungdo Island, Haenam; 27, Jung-ri and Mokdo Island, Bogildo Island; 28, Chujado Island and Sangchujado Island; 29, Gimnyeong; 30, Seongsanpo; 31, Seogwipo and Seogwipo Breakwater; 32, Munseom Island and Hangaechang in Munseom Island; 33, Beomseom Island; 34, Daepo; 35, Hyeongjeseom Island; 36, Marado Island; 37, Moseulpo; 38, Chaguido Island; 39, Biyangdo Island; 40, Gaerinyeo Island, Geumdongyeo Island and Mangbuseok, Gageodo Island; 41, Manjaedo Island; 42, Dwitdaemok, Gonchon, Jin-ri and Sa-ri, Heuksando Island; 43, Chaeseokgang Breakwater, Gunghang, Gyeokpo and Mohang, Gyekpo; 44, Daehyeongjedo Island, Wido Island; 45, Byeonsan beach; 46, Naecho-dong, Gimje; 47, Jangjado Island, Maldo Island, Sinsido Island, and Sohoenggyeongdo Island, Gogunsan Islands; 48, Burando Island, Daecheon, Dukseom Island, Mongdeokdo Island, Oehyeonggyeondo Island, Seokdo Island, Sohoenggyeondo Island and Sudo Island, Boryeong; 49, Geomeunyeo Island, Ocheon; 50, Yeongheungdo Island; 51, Jin-ri, Deokjeokdo Island.

Genus Membranipora de Blainville, 1830

124, figs. 14-18; Liu et al., 2001, p. 416, pl. 10, figs. 3-6.

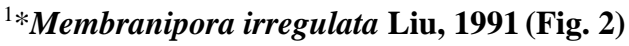

Membranipora irregulata Liu, 1991, p. 57, fig. 1; 1992, p. $\quad$ Material examined. Byeonsan beach, 8 Apr. 1993 (J.E. Seo).

\footnotetext{
1*불규칙막이끼벌레 (신칭)
} 


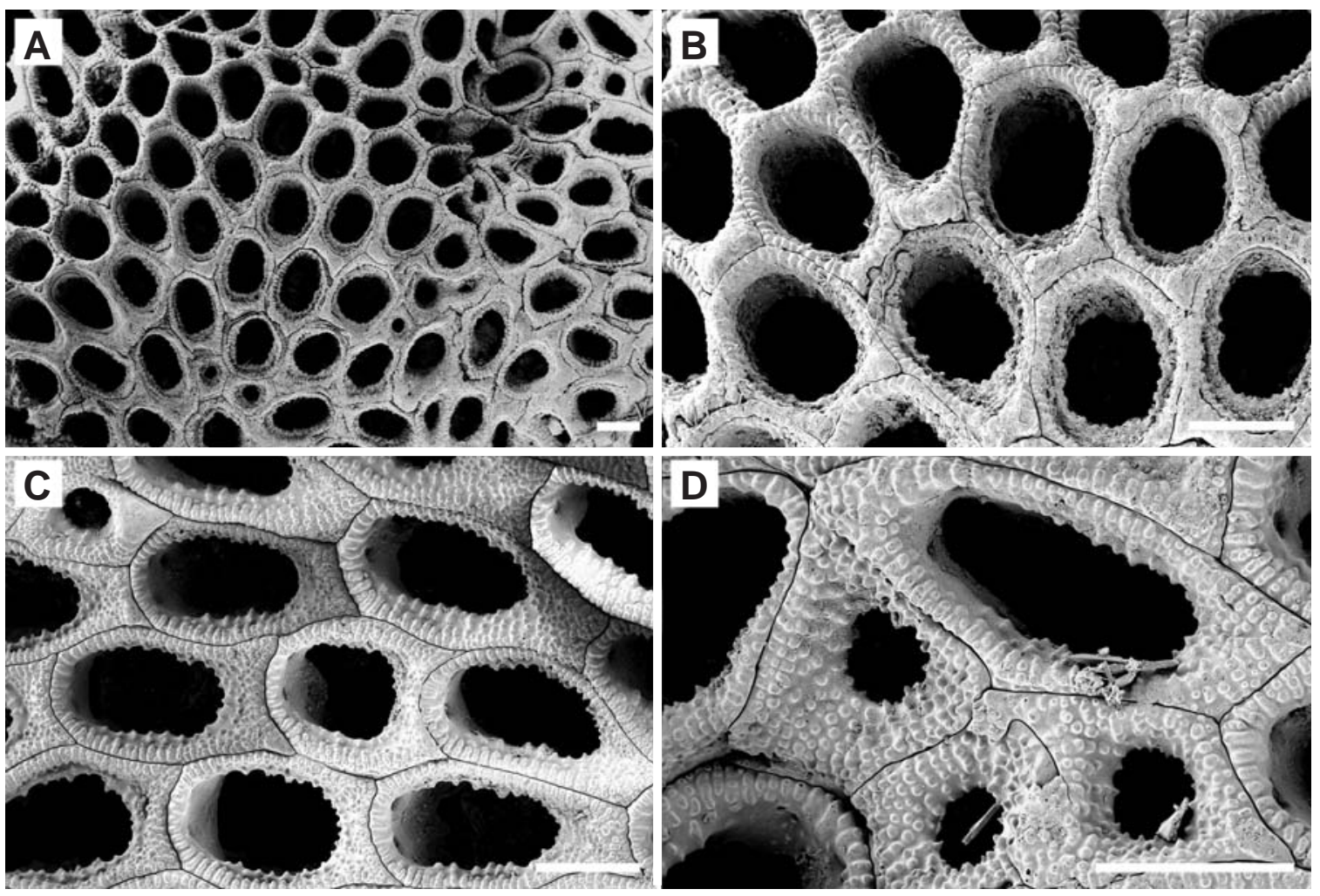

Fig. 2. Membranipora irregulata Liu, 1992. A, arrangement of zooids; B, zooids with blunt tubercles on cryptocyst; C, zooids showing cryptocyst without tubercles; D, bleached zooids remaining chitinous spines. Scale bars $=0.2 \mathrm{~mm}(A-D)$.

Substratum. Gastropod shells.

Description. Colony encrusting gastropod shells; unilamellar or forming multilaminar mass. Zooecium somewhat regular or radial in arrangement, $0.28-0.30 \mathrm{~mm}$ wide, $0.39-0.44$ $\mathrm{mm}$ long, quadrangular, pentagonal or elongate-hexagonal, angular at their four corners; outlines marked by very distinct dark brown lines. Opesia and cryptocyst covered by frontal membrane occupying whole frontal area. Mural rim salient and bead-like. Cryptocyst well developed proximally than distally and laterally, serrated on its inner border, granulated densely and roughly on its surface. No gymnocyst. Two multiporous mural porechambers on transverse wall near proximal wall. One or two blunt tubercles sometimes present on proximal cryptocyst of some zooids, mostly lacking. Kenozooids intercalated among autozooids, much smaller than autozooids, variable in size and shape, having frontal membrane, opesia and extensive cryptocyst with granular surface and serrated inner border.

Remarks. Chitinous spinules on the surface of membrane and operculum which are known as variable in number and located irregularly on surface (Liu, 1991) were not observed in the present work because the frontal membrane and oper- culum was already removed. However, some of chitinous spinules were fortunately found among the zooids. Single or a pair of blunt tubercles are seen in Korean specimens in comparison with the Chinese one showing spherical tubercles. All of the kenozooids in our specimen have the opesia while some kenozooids of Chinese ones were recorded to have no opesia.

Distribution. Korea (Yellow Sea) and South China Sea.

\section{Membranipora perfragilis (MacGillivray, 1881)}

Material examined. Naecho-dong, Gimje, 26 Oct. 1999 (S.J. Seo); Chaguido Island, 6 Nov. 2000 (J.I. Song) by SCUBA diving from $25 \mathrm{~m}$ in depth; Tongyeong Marine Ranch, 9 Aug. 2004 (J.E. Seo) by SCUBA diving from 10-20 $\mathrm{m}$ in depth.

Substratum. Seaweeds stem.

Remarks. This species encrusts corals and the stem of seaweeds, and is the typical fouling bryozoan frequently attaching to ropes hanging on the wharf and aquaculture cages.

Distribution. Pacific, including Japan and all coasts of southern Korea. 

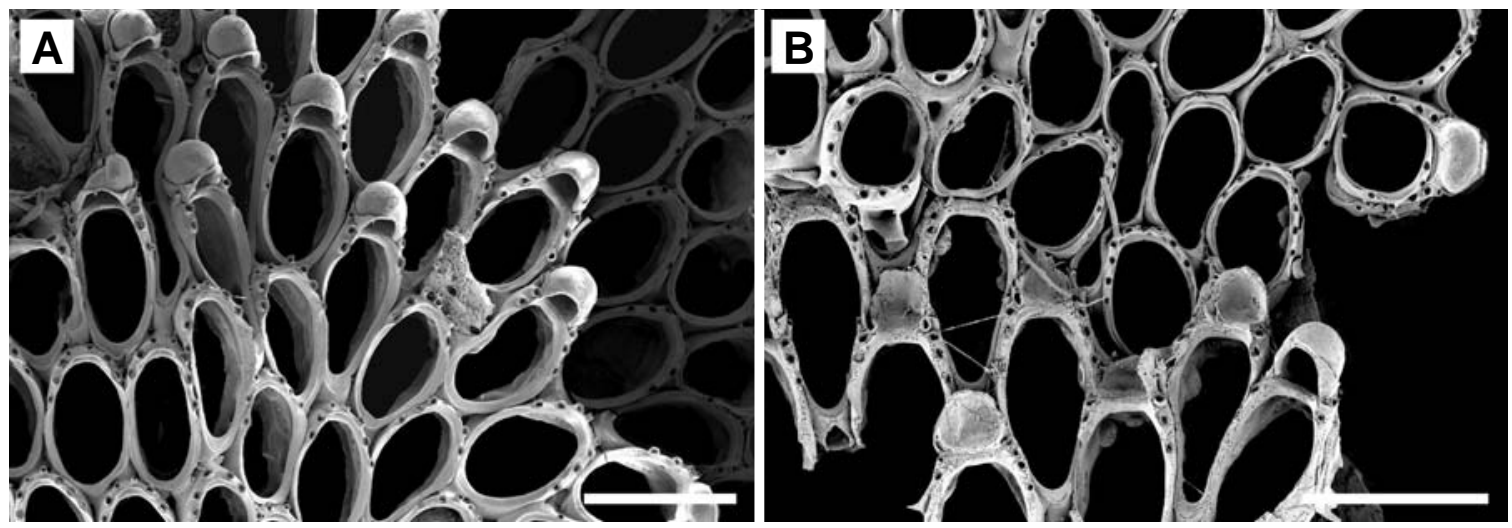

Fig. 3. Callopora inaviculata n. sp. A, arrangement of ovicellate zooids; B, zooid showing intact spine. Scale bars=0.5 mm (A, B).

\section{Membranipora savartii (Audouin, 1826)}

Material examined. Chaguido Island, 8 Jun. 2000 (J.I. Song); Munseom Island, Jeju-do, 11 Jun. 2000 (J.I. Song); Sangjuri, Namhaedo Island, 3 Dec. 2002 (J.E. Seo).

Substratum. Cement test panels.

Remarks. This species is a fouling bryozoan that has been collected from fishing nets. It is newly reported from the South Sea.

Distribution. Cosmopolitan. In Korea, it is found from the South Sea, Jeju-do and Yellow Sea.

\section{Membranipora serrilamella Osbrun, 1950}

Material examined. Wangdolcho, Uljin, 25 Aug. 2002 (J.E. Seo) by SCUBA diving from $15 \mathrm{~m}$ in depth; Taedo Island, Tongyeong, 28 Jun. 2006 (J.E. Seo); Yujado Island, Tongyeong, 29 Jun. 2006 (J.E. Seo).

Substratum. Unknown.

Remarks. This species is reported for the first time from the South Sea.

Distribution. Pacific, including Japan and Korea (South Sea and Yellow Sea).

\section{Membranipora tuberculata (Bosc., 1802)}

Material examined. Gujora, Geojedo Island, 13 Jul. 1999 (S. Shin); Hyangmyeongchon, Geojedo Island, 15 Jul. 1999 (S. Shin); Yonguimeori, Daejin, 16 Sep. 1999 (J.E. Seo); Beomseom Island, Jeju-do, 29 Nov. 2000 (J.I. Song) by SCUBA diving from $30 \mathrm{~m}$ in depth; Munseom Island, Jeju-do, 24 Feb. 2003 (J.E. Seo) from $17 \mathrm{~m}$ in depth.

Substratum. Seaweeds and stones.

Remarks. This species is usually found to encrust kelps such as Ecklonia cava. As a fouling species, it also attaches to buoys and plastic pipes.

Distribution. Cosmopolitan. In Korea, it is found from the East Sea, South Sea, and Jeju-do.

Family Electridae Stach, 1937

Genus Electra Lamouroux, 1816

Electra tenella (Hincks, 1880)

Material examined. Sangju-ri, Namhaedo Island, 3 Dec. 2002 (J.E. Seo).

Substratum. Cement test panels.

Remarks. This species is one of the fouling bryozoans which attach on the cement panels made for the ecological experiment and was also found from the test panels which were set up in the power plants at Wolseong and Seocheon.

Distribution. Cosmopolitan. In Korea, it is found from the East Sea, South Sea and Yellow Sea.

Suborder Flustrina Smitt, 1868

Superfamily Calloporoidea Norman, 1903

Family Calloporidae Norman, 1903

Genus Callopora Gray, 1848

$1 *$ Callopora inaviculata n. sp. (Fig. 3)

Material examined. Holotype: One colony from Geomeunyeo Island, Ocheon $\left(36^{\circ} 24^{\prime} 20.35^{\prime \prime} \mathrm{N}, 126^{\circ} 27^{\prime} 40.56^{\prime \prime} \mathrm{E}\right), 6$ Apr. 2003 (Y.H. Gong and K.B. Lee) by SCUBA diving from 5 $\mathrm{m}$ in depth. Paratype: One colony from same as holotype. Holotype will be deposited in the National Institute of Biological Resources, Korea. Paratype is kept in the collection of the corresponding author.

Substratum. Oyster shells.

Description. Colony encrusting oyster shells, unilamellar.

1*민조두체고운이끼벌레 (신칭) 

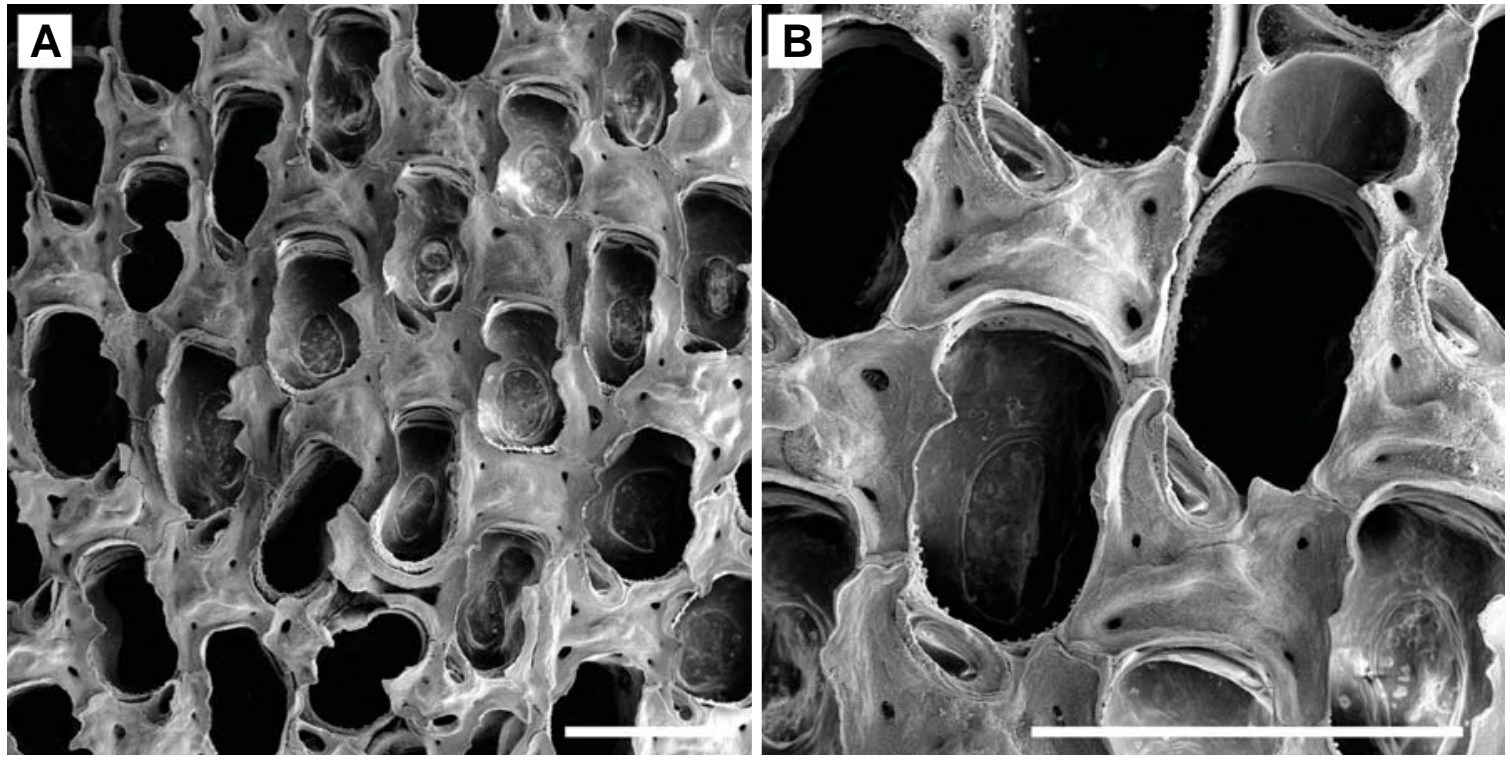

Fig. 4. Tegella crenulata (Okada, 1929). A, zooids with crenulated opesia; $B$, ovicellate zooids with avicularium. Scale bars $=0.5 \mathrm{~mm}$ $(A, B)$.

Zooids separated distinctly by deep grooves. Zooecium $0.26-$ $0.27 \mathrm{~mm}$ wide, $0.44-0.53 \mathrm{~mm}$ long, oval or elongate elliptical. Gymnocyst and cryptocyst rarely developed, but gymnocyst somewhat developed proximally, raised in some zooids. Opesia very large, occupying entire surface of front, surrounded by three pairs of long spines facing inward on disto-lateral walls. A pair of spines on distal end directed distally. No avicularium. Ovicell hyperstomial; entooecium smooth; ectooecium having membranous triangular area frontally.

Remarks. Large number of species of Callopora have numerous spines along the opesia border ranging 4-11 pairs in total. This new species is thus easily distinguished from the other species of Callopora in having only three pairs of spines. This new species is also characteristic of having no avicularium. Five species of $C$. depressa Cook, 1968, C. derjugini Kluge, 1915, C. discreta Hincks, 1862, C. obesa Kluge, 1952 and $C$. whiteavesi Norman, 1903 have no avicularium. However, three species (C. derjugini, $C$. obesa and $C$. whiteavesi) are circumpolar species, and the rest two species ( $C$. depres$s a$ and $C$. discreta) inhabit the Atlantic Ocean. In addition, the latter two species show the difference from new speices by having 6-11 pairs of spines, and 4-5 pairs, respectively (Mawatari and Mawatari, 1980). The other species of Korean Callopora, C. lineata (Linné, 1758) was also found only from the Yellow Sea as this new species.

Etymology. The scientific name is derived from in, Latin, without, referring to having no avicularium.
Genus Cauloramphus Norman, 1909

Cauloramphus korensis Seo, 2001

Material examined. Yujado Island, Tongyeong, 29 Jun. 2006 (J.E. Seo); Daehyeongjedo Island, Wido Island, 13 Jun. 2007 (B.S. Min); Dukdo Island, Boryeong, 25 Jun. 2007 (J.E. Seo); Seokdo Island and Bulando Island, Boryeong, 26 Jun. 2007 (J.E. Seo).

Substratum. Unknown.

Remarks. This species is newly added from the South Sea and easily recognizable with its purplish brown spines.

Distribution. Korea (East Sea, South Sea and Yellow Sea).

Genus Tegella Levinsen, 1909

${ }^{1} *$ Tegella crenulata (Okada, 1929) (Fig. 4)

Ellisina crenulata Okada, 1929, p. 12, pl. 4, fig. 1.

Tegella crenulata: Sakakura, 1935, p. 107; Okada and Mawatari, 1938, p. 449, pl. 24, figs. 2, 3; Mawatari, 1952, p. 263; Mawatari and Mawatari, 1980, p. 98, fig. 35.

Material examined. Tongyeong Marine Ranch, 29 Aug. 2004 (J.E. Seo) by SCUBA diving from 10-20 $\mathrm{m}$ in depth.

Substratum. Unknown.

Description. Colony encrusting seaweeds, shells and stones, and forming somewhat thick and grayish incrustation. Zooecia elongated quadrangular, 0.31-0.40 mm wide, 0.65-0.71 $\mathrm{mm}$ long, arranged alternatively in radiating lines, separated by indistinct interzooidal grooves by secondary calcification.

\footnotetext{
$1 *$ 연거친거미이끼벌레 (신칭)
} 
Frontal wall covered by frontal membrane. Gymnocyst developed a little proximally with a few of marginal pores, but soon heavily calcified causing to be thick and undulating to conceal frontal avicularia or ovicell. Lateral expansion of proximal gymnocyst of neighbouring zooid usually projecting into opesia to make its margin irregular and crenulated near middle. Opesia elongate oval, 0.28-0.35 mm wide, 0.49$0.58 \mathrm{~mm}$ long occupying about $2 / 3$ of frontal surface. Cryptocyst not developed in older zooids. No spines. A single avicularium, situated laterally on proximal gymnocyst, becoming immersed in older zooids formed by secondary calcification, directing obliquely distally and upward, elongate triangular directing obliquely distally and upward, with no cross bar. Ovicell hemispherical, as wide as opesia, broader and long, immersed in heavily calcified, margin of which comprise thick, curved transverse ridge. Ancestrula not observed.

Remarks. This species resembles to Tegella incrustans Silén, 1941. However, the avicularium is situated in the center of the gymnocyst in T. incrustans, whereas the one of this new species is located in the lateral side of the gymnocyst when it is associated with ovicell. Besides, the zooecium and opesia are smaller than the ones of Japanese specimen (Mawatari and Mawatari, 1980). Also this species shows the difference from $T$. incrustans in having no spine.

Distribution. Korea (South Sea) and Japan.

\section{Tegella incrustans Silén, 1941}

Material examined. Gaerinyeo Island, Gageodo Island, 13 Aug. 1998 (J.E. Seo) by SCUBA diving from 18-23 $\mathrm{m}$ in depth; Baekdo Island, Geomundo Island, 28 Mar. 2002 (J.J. Sim) by SCUBA diving from $20 \mathrm{~m}$ in depth.

\section{Substratum. Sponges.}

Remarks. Most of the species belonging to Tegella are not easy species to identify because of its heavy calcification. This species is a fouling bryozoan which has been collected from the plastic buoy.

Distribution. Korea (East Sea, South Sea and Yellow Sea) and Japan.

Family Antroporidae Vigneaux, 1949

Genus Antropora Norman, 1903

Antropora tincta (Hastings, 1930)

Material examined. Jung-ri, Bogildo Island, 11 Aug. 1995 (J.E. Seo) from fishing nets; Gaerinyeo Island, Gageodo Island, 13 Aug. 1998 (J.E. Seo) by SCUBA diving from 18$23 \mathrm{~m}$ in depth; Sudo Island, Boryeong, 27 Jun. 2007 (J.E. Seo).

Substratum. Hermit crab.
Remarks. This species is easily recognizable with its pinkish color. The Yellow Sea is added to the distribution of this species.

Distribution. Korea (South Sea and Yellow Sea), Japan, Pacific and Atlantic.

Family Chaperiidae Jullien, 1888

Genus Chaperia Jullien, 1891

Chaperia acanthia (Lamouroux, 1825)

Material examined. Gaerinyeo Island, Gageodo Island, 13 Aug. 1998 (J.E. Seo) by SCUBA diving from 18-23 m in depth.

Substratum. Unknown.

Remarks. This species is newly collected from the Yellow Sea.

Distribution. Korea (South Sea and Yellow Sea) and Japan.

Superfamily Buguloidea Gray, 1848

Family Bugulidae Gray, 1848

Genus Bugula Oken, 1815

Bugula californica Robertson, 1905

Material examined. Gaeseom Island and Keungaeseom Island, Sacheon, 14 Jun. 2000 (J.E. Seo) by SCUBA diving from $5 \mathrm{~m}$ in depth; Sangju-ri, Namhaedo Island, 2, 3 Nov. 2002 (J.E. Seo) from test panels; Sangju-ri, Namhaedo Island, 2 Feb. 2002 (J.E. Seo) from test panels; Uldo Island, Tongyeong, 27 Jun. 2006 (J.E. Seo); Hwado Island, Tongyeong, 29 Jun. 2006 (J.E. Seo).

Substratum. Cement test panels, seaweeds and plastic bottles. Remarks. This species is a fouling bryozoan.

Distribution. Cosmopolitan.

\section{Bugula dentata (Lamouroux, 1816)}

Material examined. Seongsanpo, 9 Jun. 2000 (J.I. Song); Beomseom Island, Jeju-do, 3 Nov. 2000 (J.I. Song) by SCUBA diving from $30 \mathrm{~m}$ in depth; Marado Island, 4 Nov. 2000 (J.I. Song) by SCUBA diving from $30 \mathrm{~m}$ in depth; Chaguido Island, 6 Nov. 2000 (J.I. Song) by SCUBA diving from 25 $\mathrm{m}$ in depth; Gaerinyeo Island, Gageodo Island, 13 Aug. 1998 (J.E. Seo) by SCUBA diving from 18-23 $\mathrm{m}$ in depth.

Substratum. Worm tubes.

Remarks. Gageodo Island belonging to the Yellow Sea is the additional locality for this species.

Distribution. Cosmopolitan.

\section{Bugula neritina (Linné, 1758)}

Material examined. Mokdo Island, Bogildo Island, 11 Aug. 

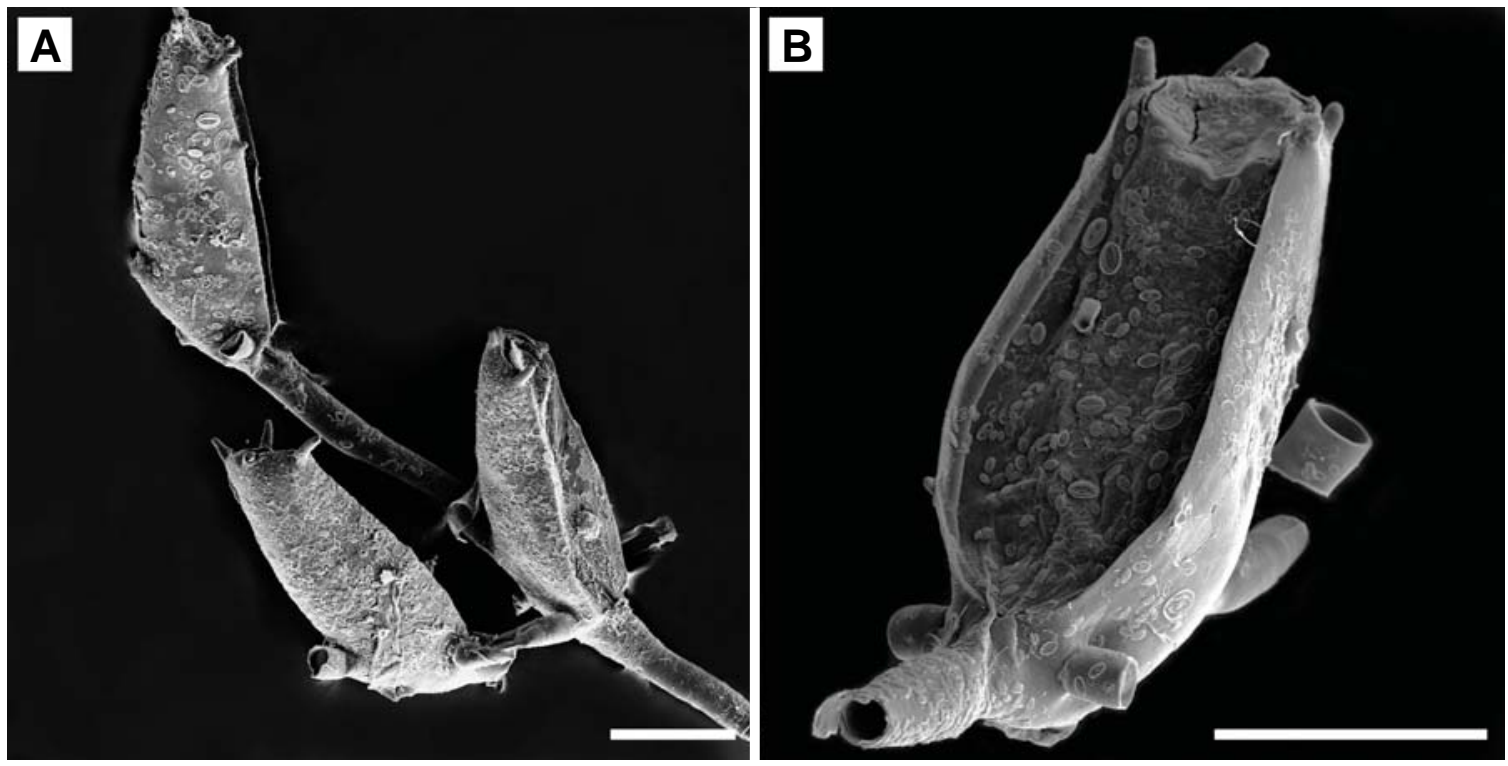

Fig. 5. Beania regularis Thornely, 1916. A, arrangement of zooids showing four connection tubes; B, close-up of zooid showing four spines on distal end. Scale bars $=0.2 \mathrm{~mm}(\mathrm{~A}, \mathrm{~B})$.

1995 (J.E. Seo); Susan, Geojedo Island, 29 Jan. 1997 from $10 \mathrm{~m}$ in depth; Sobongdae, Yangpo, 14 Sep. 1999 (J.E. Seo); Keungaeseom Island, Sacheon, 14 Jun. 2000 (J.E. Seo) by SCUBA diving from $5 \mathrm{~m}$ in depth; Jungpyeon, Gollido, 23 Jul. 2001 (J.E. Seo); Sangju-ri, Namhaedo Island, 2 Nov. 2002 (J.E. Seo) from test panels; Sangju-ri, Namhaedo Island, 3 Dec. 2002 (J.E. Seo) from test panels; Sangju-ri, Namhaedo Island, 17 Feb. 2003 (J.E. Seo) from test panels; Tongyeong Marine Ranch, 29 Aug. 2004 (J.E. Seo) by SCUBA diving from 10-20 m in depth; Chukdo Island, Tongyeong, 26 Jun. 2006 (J.E. Seo); Godo Island, Tongyeong, 27 Jun. 2006 (J.E. Seo); Uldo Island, Tongyeong, 27 Jun. 2006 (J.E. Seo); Daehyeongjedo Island, Wido Island, 13 Jun. 2007 (J.E. Seo).

Substratum. Shells, ropes hanging on the wharf, cement test panels and seaweeds.

Remarks. Bugula neritina is a cosmopolitan species distributed through the ocean as a typical fouling bryozoan. It is remarkable that this is not yet found from Jejudo Island waters, though. Bugula neritina looks similar to B. dentata in bushy shape of colony, however the latter which is dark green in color clearly differs from the former which is reddish brown.

Distribution. Cosmopolitan. In Korea, it is found from the East Sea, South Sea and Yellow Sea.

\section{Bugula robusta MacGillivray, 1869}

Material examined. Junghangdo Island, Tongyeong, 27 Jun. 2006 (J.E. Seo).
Substratum. Unknown.

Distribution. Cosmopolitan. In Korea, it is found only from the South Sea.

\section{Bugula subglobosa Harmer, 1926}

Material examined. Chaguido Island, 6 Jun. 2000 (J.I. Song) by SCUBA diving from $25 \mathrm{~m}$ in depth; Beomseom Island, Jeju-do, 10 Jun. 2001 (J.I. Song) by SCUBA diving from 35 $\mathrm{m}$ in depth.

Substratum. Worm tubes.

Distribution. Pacific, including Japan and Korea (South Sea and Jeju-do).

\section{Bugula umbelliformis (Yanagi and Okada, 1918)}

Material examined. Daehyeongjedo Island, Wido Island, 13 Jun. 2007 (J.E. Seo).

Substratum. Unknown.

Remarks. This species is reported for the first time from the Yellow Sea.

Distribution. Korea (East Sea, South Sea and Yellow Sea) and Japan.

Family Beaniidae Canu and Bassler, 1927

Genus Beania Johnston, 1840

Beania discodermiae (Ortmann, 1890)

Material examined. Gaerinyeo, Gageodo Island, 13 Aug. 
1998 (J.E. Seo) by SCUBA diving from 18-23 $\mathrm{m}$ in depth. Substratum. Unknown.

Remarks. This species is a fouling bryozoan collected from fishing nets. The Yellow Sea is the first record for this species in Korea.

Distribution. Pacific, including Japan and all coasts of southern Korea.

\section{Beania hexaceras (Ortmann, 1890)}

Material examined. Chuksa, Gampo, 2 Jul. 1998 (S. Shin); Taedo Island, Tongyeong, 28 Jun. 2006 (J.E. Seo); Bongdo Island, Tongyeong, 28 Jun. 2006 (J.E. Seo).

Substratum. Unknown.

Distribution. Japan and all coasts of southern Korea.

\section{${ }^{1 * B e a n i a}$ regularis Thornely, 1916 (Fig. 5)}

Beania regularis Thornely, 1916, p. 161, text-fig. 6; Harmer, 1926, p. 418, pl. 28, figs. 11, 12; Hastings, 1932, p. 409; Mawatari, 1965, p. 607, fig. 78e, f; Liu, 1984, p. 264, fig. 9; Mawatari and Mawatari, 1986, p. 85, fig. 5; Liu et al., 2001, p. 478 , pl. 26, fig. 1.

Material examined. Jijukdo Island, 2 Jul. 1991 (J.E. Seo); Chaeseokgang breakwater, Gyekpo, 3 May 1997 (J.E. Seo); Samjeong, Guryongpo, 17 Jul. 2001 (S. Shin); Jeungdo Island, Haenam, 25 Mar. 2005 (Y.H. Gong and B.S. Min).

Substratum. Shells of Brachiopoda, Shells of Mollusca, worm tubes and stones.

Description. Colony attaching to substrata by rootlets given off by basal surface, usually one by each zooecium near proximal end of its expanded part. Neighbour zooids forming meshes by four connecting tubes protruding from proximal end. Zooecia elongate elliptical, 0.18-0.19 mm wide, 0.43-0.57 mm long, its expanded part stands up at considerable angle from basal network. Opesia occupying whole front, widened proximally. Proximal part of zooecium long, tubular, which connecting to basal tube rising from mother zooid. Lateral connecting tubes arising in both proximal ends. Spines two or four, very small, restricted to distal end. No avicularium and ovicell found.

Remarks. Harmer (1926) described that this species had usually three spines and occasionally two or four. However, our specimens have usually four spines, sometimes two. No avicularium was found in our specimens. Harmer also described that the avicularium was rarely found. Colony can be visible only under microscope because it looks thin thread in shape.

Distribution. Korea (South Sea and Yellow Sea) and western
Pacific.

\section{Beania vegae Silén, 1941}

Material examined. Susan, Geojedo Island, 29 Jan. 1997 (J.E. Seo) from $10 \mathrm{~m}$ in depth; Chaguido Island, 8 Jun. 2000 (J.I. Song); Solseom Island, Sacheon, 12 Jun. 2000 (J.E. Seo); Bakdeungdo Island, Sacheon, 13 Jun. 2000 (J.E. Seo), Godo Island, Tongyeong, 27 Jun. 2006 (J.E. Seo); Bongdo Island, Tongyeong, 28 Jun. 2006 (J.E. Seo); Daejangdudo Island, Tongyeong, 28 Jun. 2006 (J.E. Seo); Jangdo Island, Tongyeong, 29 Jun. 2006 (J.E. Seo).

Substratum. Seaweeds and shells.

Distribution. Korea (South Sea) and Japan.

Family Candidae d'Orbigny, 1851

Genus Amastigia Busk 1852

Amastigia rudis (Busk, 1852)

Material examined. Seongsanpo, 9 Jun. 2000 (J.I. Song); Marado Island, 4, Nov. 2000 (J.I. Song) by SCUBA diving from $30 \mathrm{~m}$ in depth; Seongsanpo, 5 Nov. 2000 (J.I. Song) by SCUBA diving from $20 \mathrm{~m}$ in depth; Beomseom Island, Jejudo, 21 Feb. 2001 (J.I. Song) by SCUBA diving from $20 \mathrm{~m}$ in depth; Marado Island, 7 Jun. 2001 (J.I. Song); Munseom Island, Jeju-do, 26 Feb. 20 (J.E. Seo) by SCUBA diving from $30 \mathrm{~m}$ in depth; Gaerinyeo Island, Gageodo Island, 13 Aug. 1998 (J.E. Seo) by SCUBA diving from 18-23 $\mathrm{m}$ in depth. Substratum. Unknown.

Remarks. This species is known to be a fouling bryozoan encrusting the anchors.

Distribution. Pacific including Japan and all coasts of southern Korea, and Indian.

\section{Amastigia xishensis Xixing, 1984}

Material examined. Seongsanpo, 5 Nov. 2000 (J.I. Song) by SCUBA diving from $20 \mathrm{~m}$ in depth; Seongsanpo, 9 Jun. 2001 (J.I. Song) by SCUBA diving from $20 \mathrm{~m}$ in depth.

Substratum. Unknown.

Remarks. This species is endemic to the Far East which is collected only from Jejudo Island waters and Chinese Seas so far.

Distribution. Pacific, including Korea (Jeju-do).

Genus Caberea Lamouroux, 1816

Caberea boryi (Audouin, 1826)

Material examined. Chaguido Island, 8 Jun. 2000 (J.I. Song);

\footnotetext{
$1 *$ 아기왕관콩이끼벌레 (신칭)
} 
Seongsanpo, 9 Jun. 2000 (J.I. Song); Beomseom Island, Jejudo, 3 Nov. 2000 (J.I. Song) by SCUBA diving from $30 \mathrm{~m}$ in depth; Marado Island, 22 Feb. 2001 (J.I. Song) by SCUBA diving by $18 \mathrm{~m}$ in depth; Gaerinyeo Island, Gageodo Island, 13 Aug. 1998 (J.E. Seo) by SCUBA diving from 18-23 $\mathrm{m}$ in depth.

Substratum. Seaweeds.

Remarks. This species is cosmopolitan, however the Yellow Sea is added in its Korean distribution herein and thus the East Sea remains to be investigated.

Distribution. Cosmopolitan. In Korea, it is found from the South Sea, Jeju-do and Yellow Sea.

\section{Caberea lata Okada, 1923}

Material examined. Beomseom Island, Jeju-do, 3 Nov. 2000 (J.I. Song) by SCUBA diving from $30 \mathrm{~m}$ in depth; Marado Island, 4 Nov. 2000 (J.I. Song) by SCUBA diving from 30 $\mathrm{m}$ in depth; Seongsanpo, 5 Nov. 2000 (J.I. Song) by SCUBA diving from $20 \mathrm{~m}$ in depth; Beomseom Island, Jeju-do, 21 Feb. 2001 (J.I. Song) by SCUBA diving from $20 \mathrm{~m}$ in depth; Marado Island, 22 Feb. 2001 (J.I. Song) by SCUBA diving from $18 \mathrm{~m}$ in depth; Marado Island, 7 Jun. 2001 (J.I. Song); Beomseom Island, Jeju-do, 10 Jun. 2001 (J.I. Song) by SCUBA diving from $35 \mathrm{~m}$ in depth; Baekdo Island, Geomundo Island, 28 Feb. 2002 (J.J. Sim) by SCUBA diving from 20 $\mathrm{m}$ in depth; Gaerinyeo Island, Gageodo Island, 13 Aug. 1998 (J.E. Seo) by SCUBA diving from 18-23 m in depth; Tongyeong Marine Ranch, 29 Aug. 2004 (J.E. Seo) by SCUBA diving from 10-20 $\mathrm{m}$ in depth; Pildo Island, Tongyeong, 28 Jun. 2006 (J.E. Seo); Taedo Island, Tongyeong, 28 Jun. 2006 (J.E. Seo); Yujado Island, Tongyeong, 29 Jun. 2006 (J.E. Seo).

Substratum. Sponges and barnacles.

Remarks. Caberea lata is distinguishable from $C$. hataii Okada, 1929 in having no scutum. This species is a fouling bryozoan collected from fishing nets.

Distribution. Pacific including Japan and all coasts of southern Korea, and Indian.

Genus Scrupocellaria van Beneden, 1845

Scrupocellaria maderensis Busk, 1860

Material examined. Gaerinyeo Island, Gageodo Island, 13 Aug. 1998 (J.E. Seo) by SCUBA diving from $18-23 \mathrm{~m}$ in depth.

Substratum. Unknown.

Remarks. The Yellow Sea is added to the Korean distribution of this species.

Distribution. Pacific including Japan and Korea (South Sea, Jeju-do and Yellow Sea), and Atlantic.
Genus Tricellaria Fleming, 1828

Tricellaria occidentalis (Trask, 1857)

Material examined. Mokdo Island, Bogildo Island, 11 Aug. 1995 (J.E. Seo); Dangsa, Ulsan, 1 Jul. 1998 (S. Shin); Chuksa, Gampo, 2 Jul. 1998 (S. Shin); Daechilgido Island, Wando Island, 14 Jun. 1999 (Y.H. Gong); Heungnam, Geojedo Island, 13 Jul. 1999 (S. Shin); Hyangmyeonchon, Geojedo Island, 15 Jul. 1999 (S. Shin); Sa-ri, Heuksando Island, 11 Aug. 1999 (J.E. Seo); Dwitdaemok, Heuksando Island, 12 Aug. 1999 (J.E. Seo); Changpo 2-ri, Gyeongjeong, 13 Sep. 1999 (J.E. Seo); Ulgi light house, 14 Sep. 1999 (J.E. Seo); Masan, Balsan, 14 Sep. 1999 (J.E. Seo); 1-ri, Balsan, 15 Sep. 1999 (J.E. Seo); Yonguimeori, Daejin, 16 Sep. 1999 (J.E. Seo); Geondal, Yeongdeok, 16 Sep. 1999 (J.E. Seo); Munseom Island, Jeju-do, 6 Jun. 2001 (J.I. Song); Sangju-ri, Namhaedo Island, 2 Nov. 2002 (J.E. Seo) from test panels; Gaerinyeo Island, Gageodo Island, 13 Aug. 1998 (J.E. Seo) by SCUBA diving from 18-23 $\mathrm{m}$ in depth; Ido Island, Tongyeong, 27 Jun. 2006 (J.E. Seo); Jukdo Island, Tongyeong, 29 Jun. 2006 (J.E. Seo); Jangdo Island, Tongyeong, 29 Jun. 2006 (J.E. Seo); Hodo Island, Tongyeong, 30 Jun. 2006 (J.E. Seo).

Substratum. Shells, seaweeds, colonial tunicates, sponges. Remarks. This species is not only one of three commonest fouling bryozoans, but also the second commonest in intertidal zone of South Korea.

Distribution. Pacific, including Japan and all coasts of southern Korea.

Superfamily Microporoidea Gray, 1848

Family Steginoporellidae Hincks, 1884

Genus Steginoporella Smitt, 1873

Steginoporella magnilabris (Busk, 1854)

Material examined. Baekdo Island, Geomundo Island, 28 Mar. 2002 (J.J. Sim) by SCUBA diving from $20 \mathrm{~m}$ in depth; Gaerinyeo Island, Gageodo Island, 13 Aug. 1998 (J.E. Seo) by SCUBA diving from $18-23 \mathrm{~m}$ in depth. Substratum. Sponges.

Remarks. This species is a subtropical species and has been reported from the South Sea and Jejudo Island waters of Korea so far. Gageodo Island belonging to the Yellow Sea affected by the warm current is added to the distribution of this species herein.

Distribution. Cosmopolitan. In Korea, it is found from the South Sea, Jeju-do and Yellow Sea.

Family Thalamoporellidae Levinsen, 1909

Genus Thalamoporella Hincks, 1887

Thalamoporella lioticha (Ortmann, 1890) 

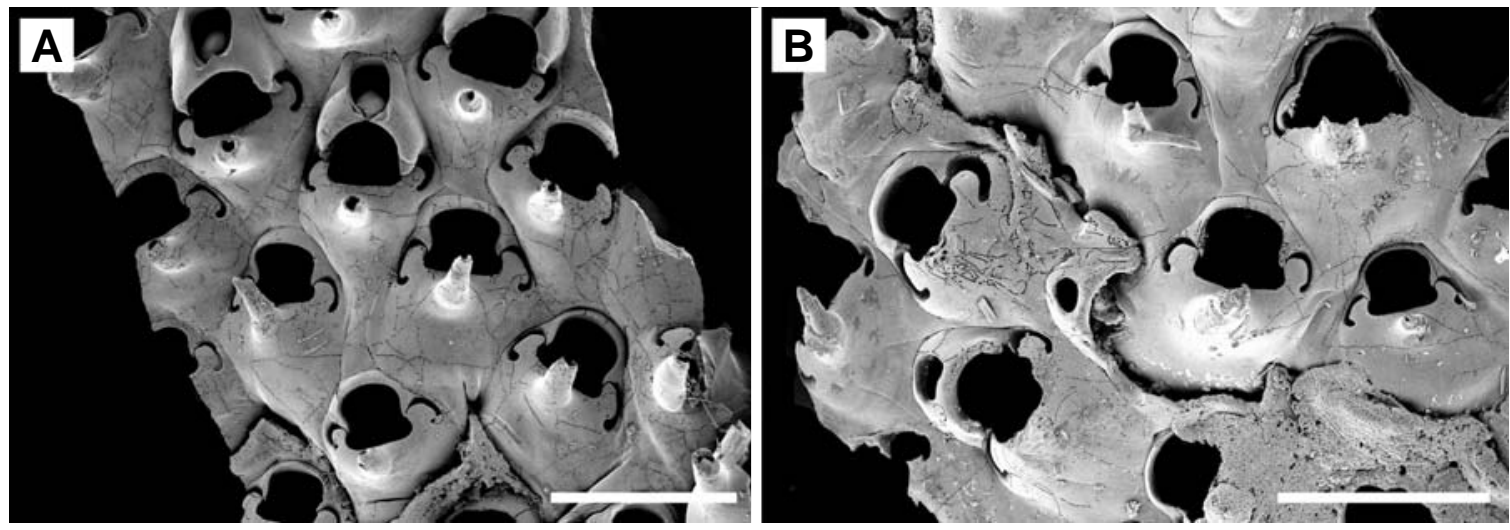

Fig. 6. Integripelta meta n. sp. A, ovicellate zooids showing conical projection just below orifice; $B$, variable ovicells and foramens in size and shape (compare with left picture). Scale bars $=0.5 \mathrm{~mm}(\mathrm{~A}, \mathrm{~B})$.

Material examined. Biyangdo Island, 12 Dec. 1988; Gaerinyeo, Gageodo Island, 13 Aug. 1998 (J.E. Seo) by SCUBA diving from 18-23 m in depth; Geumdongyeo, Gageodo Island, 15 Aug. 1998 (J.E. Seo) by SCUBA diving from $27 \mathrm{~m}$ in depth.

Substratum. Unknown.

Remarks. This species is a fouling bryozoan attaching the ropes hanging by the wharf. The Yellow Sea is added to the distribution of this species.

Distribution. Pacific, including Japan and Korea (South Sea, Jeju-do and Yellow Sea).

\section{Thalamoporella sibogae Soule, Soule and Chaney, 1992}

Material examined. Seogwipo, 12 Apr. 1975; Daepo, Jejudo, 16 Jan. 1985; Hyeongjeseom Island, Moseulpo, 21 Jul. 1998 (H.S. Go) by SCUBA diving from 15-20 $\mathrm{m}$ in depth. Substratum. Stones.

Distribution. Korea (Jeju-do) and southwestern Pacific.

Superfamily Cellarioidea Lamouroux, 1821

Family Cellariidae Lamouroux, 1821

Genus Cellaria Ellis and Solander, 1786

Cellaria punctata (Busk, 1852)

Material examined. Manjaedo, 23 Aug. 1988 (J.K. Jae) from $25 \mathrm{~m}$ in depth; Daepo, Geojedo Island, 8 Jul. 1996 (J.E. Seo) from $70 \mathrm{~m}$ in depth; Marado Island, 4 Nov. 2000 (J.I. Song) by SCUBA diving from $30 \mathrm{~m}$ in depth; Beomseom Island, Jeju-do, 10 Jun. 2001 (J.I. Song) by SCUBA diving from 35 $\mathrm{m}$ in depth; Marado Island, 16 Aug. 2001 (J.I. Song); Baekdo Island, Geomundo Island, 28 Mar. 2002 (J.J. Sim) by SCUBA diving from $20 \mathrm{~m}$ in depth; Gaerinyeo Island, Gageodo Island 13 Aug. 1998 (J.E. Seo) by SCUBA diving from $18-23 \mathrm{~m}$ in depth; Gampo Port, 25 Feb. 2003 (Y.H. Gong); Bongdo Island, Tongyeong, 28 Jun. 2006 (J.E. Seo).

Substratum. Fishing nets (70 m deep), sponges and stones.

Remarks. This species is newly reported as a fouling bryozoan herein.

Distribution. Cosmopolitan.

Suborder Ascophora Levinsen, 1909

Infraorder Acanthostega Levinsen, 1902

Superfamily Catenicellidea Busk, 1852

Family Catenicellidae Busk, 1852

Genus Catenicella de Blainville, 1830

Catenicella elegans Busk, 1852

Material examined. Chaguido Island, 8 Jun. 2000 (J.I. Song); Seongsanpo, 5 Nov. 2000 (J.I. Song) by SCUBA diving from $20 \mathrm{~m}$ in depth; Chaguido Island, 6 Jun. 2000 (J.I. Song) by SCUBA diving from $25 \mathrm{~m}$ in depth; Munseom Island, Jejudo, 6 Jun. 2001 (J.I. Song); 7 Jun. 2001 (J.I. Song); Seongsanpo, 9 Jun. 2001 (J.I. Song) by SCUBA diving from $20 \mathrm{~m}$ in depth; Marado Island, 16 Jun. 2001 (J.I. Song).

Substratum. Worm tubes.

Distribution. Cosmopolitan. In Korea, it is found from the South Sea, Jeju-do and Yellow Sea.

Family Eurystomellidae Levinsen, 1909

Genus ${ }^{1 *}$ Integripelta Gordon, Mawatari and Kajihara, 2002

${ }^{2}$ Integripelta meta $\mathbf{n}$. sp.(Fig. 6)

Lepralia bilabiata: Okada, 1929, p. 24, fig. 10, pl. 2, fig. 3; Sakakura, 1935, p. 25, fig. 7.

Eurystomella bilabiata: Mawatari, 1952, p. 280; Gong and Seo, 2004, p. 14, fig. 2E [not E. bilabiata (Hincks, 1884)].

\footnotetext{
$1 *$ 민벽이끼벌레속 (신칭), ${ }^{2}$ *원뿔민벽이끼벌레 (신칭)
} 
Material examined. Holotype: One colony from Geomeunyeo Island, Ocheon ( $\left.36^{\circ} 24^{\prime} 20.35^{\prime \prime} \mathrm{N}, 126^{\circ} 27^{\prime} 40.56^{\prime \prime} \mathrm{E}\right), 6$ Apr. 2003 (Y.H. Gong and K.B. Lee) by SCUBA diving from 5 $\mathrm{m}$ in depth. Paratypes: Sa-ri, Heuksando Island, 11 Aug. 1999 (J.E. Seo); Gaerinyeo Island, Gageodo Island, 13 Aug. 1998 (J.E. Seo) by SCUBA diving from 18-23 $\mathrm{m}$ in depth; Uldo Island, Tongyeong, 27 Jun. 2006 (J.E. Seo); Hangdo Island, Tongyeong, 29 Jun. 2006 (J.E. Seo). Holotype will be deposited in the National Institute of Biological Resources, Korea. Paratypes are kept in the collection of the corresponding author.

Substratum. Oyster shells, seaweeds and rocks.

Description. Colony encrusting rocks, thin, unilamellar. Selfovergrowth found. Zooecium 0.34-0.38 mm wide, 0.54-0.61 $\mathrm{mm}$ long, contiguous, pentagonal, quincuncially arranged. Gymnocystal frontal shield flat, imperforate. Prominent spinous projection, conically pointed at end, on middle of gymnocyst, just below lower margin of zooecial orifice. Orifice nearly as long as wide, somewhat dumbbell-shaped, anter arched and rounded with proximal corners somewhat condyle-like; poster not wider than anter, proximal rim nearly straight. Orifice of maternal zooids a little larger than in autozooids. Conspicuous crescentic slits curve proximolaterally from corners of poster. Ooecium-associated kenozooid well developed, with a single large foramen, variable in size and shape. No avicularium and spine.

Remarks. Gordon et al. (2002) synonymized Eurystomella bilabiata Hincks, 1884 described by Okada (1929) with Integripelta shirayamai Gordon, Mawatari and Kajihara, 2002. However, the former is much different from the latter in having prominent spinous projection on the middle of the gymnocyst. Integripelta bilabiata by Okada is very similar to our specimens, instead. Both all the zooecia of Korean and Okada's specimens have conical projection, whereas no conical projection was found in I. shirayamai of Gordon et al. (2002). This new species also resembles to I. umbonata Gordon, Mawatari and Kajihara, 2002 in having the umbo below the orifice, however the latter has a low umbo in the centre of the gymnocyst and no long cresentic slits.

Etymology. The scientific name is derived from meta, Latin, conical column, referring to the conical projection.

Distribution. Korea (South Sea and Yellow Sea).

Infraorder Hippothoomorpha Gordon, 1989

Superfamily Hippothooidea Fischer, 1866

Family Hippothoidae Fischer, 1866

Genus Hippothoa Lamouroux, 1821

Hippothoa distans MacGillivray, 1869

Material examined. Bakdeungdo Island, Sacheon, 13 Jun.
2000 (J.E. Seo).

Substratum. Other bryozoan (Escharoides sp.).

Distribution. Cosmopolitan. In Korea, it is found only from the South Sea.

Infraorder Umbonulomorpha Gordon, 1989

Superfamily Adeonooidea Busk, 1884

Family Adeonellidae Busk, 1884

Genus Adeonella Waters, 1888

Adeonella platalea Busk (Busk, 1854)

Material examined. Chaguido Island, 8 Jun. 2000 (J.I. Song); Seongsanpo, 5 Nov. 2000 (J.I. Song) by SCUBA diving from $20 \mathrm{~m}$ in depth; Chaguido Island, 6 Jun. 2000 (J.I. Song) by SCUBA diving from $25 \mathrm{~m}$ in depth; Marado Island, 22 Feb. 2001 (J.I. Song) by SCUBA diving from $18 \mathrm{~m}$ in depth; Munseom Island, Jeju-do, 6 Jun. 2001 (J.I. Song); Seongsanpo, 9 Jun. 2001 (J.I. Song) by SCUBA diving from $20 \mathrm{~m}$ in depth; Marado Island, 16 Aug. 2001 (J.I. Song) by SCUBA diving.

Substratum. Unknown.

Remarks. This species is endemic to Jejudo Island waters so far.

Distribution. Korea (Jeju-do) and Japan.

Superfamily Umbonuloidea Canu, 1904

Family Celleporariidae Harmer, 1957

Genus Celleporaria Lamouroux, 1821

Celleporaria aperta (Hincks, 1882)

Material examined. Solseom Island, Sacheon, 12 Jun. 2000 (J.E. Seo); Jungpyeon in Gollido Island, 23 Jul. 2001 (J.E. Seo); Gaerinyeo Island, Gageodo Island, 13 Aug. 1998 (J.E. Seo) by SCUBA diving from $18-23 \mathrm{~m}$ in depth; Chukdo Island, Tongyeong, 26 Jun. 2006 (J.E. Seo); Junghangdo Island, Tongyeong, 27 Jun. 2006; Yujado Island, Tongyeong, 29 Jun. 2006 (J.E. Seo).

Substratum. Ropes hanging on the wharf.

Remarks. This species is a fouling bryozoan collected from test panels in the power plants at Wolseong and Seocheon.

Distribution. Cosmopolitan. In Korea, it is found from the East Sea, South Sea and Yellow Sea.

$1 *$ Celleporaria brunnea (Hincks, 1884) (Fig. 7)

Cellepora brunnea Hincks, 1884, p. 56; O’Donoghue and O’Donoghue, 1926, p. 21.

Holoporella brunnea: Hastings, 1930, p. 731, p. 16, fig. 7, 108-110; Osburn, 1952, p. 496, pl. 62, figs. 10-12; Soule and Duff, 1957, p. 127; Soule, 1961, p. 33; Pinter, 1969, p. 210 .

\footnotetext{
1*갈색섬유이끼벌레 (신칭)
} 

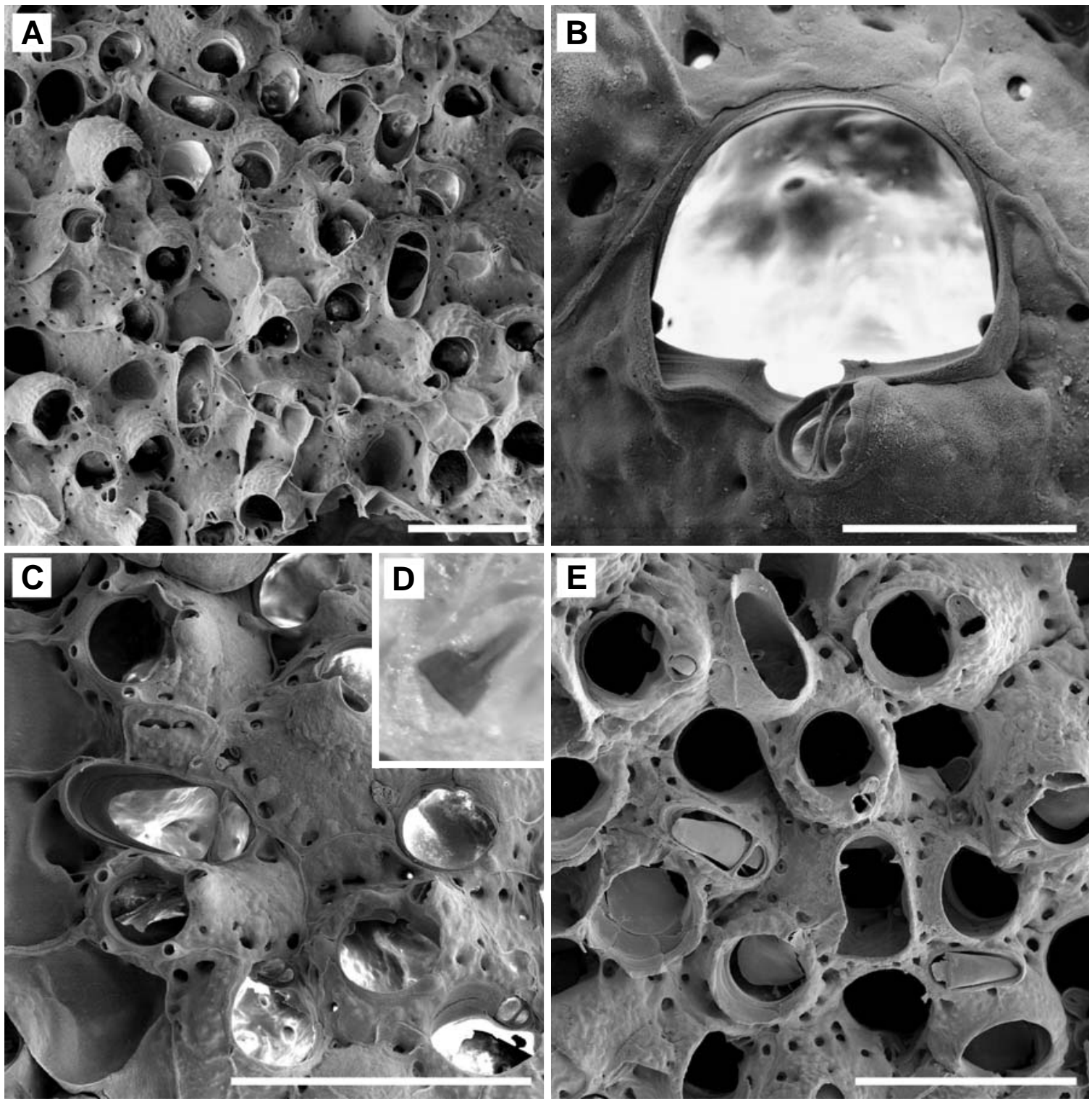

Fig. 7. Celleporaria brunnea (Hincks, 1884). A, arrangement of zooids with two spines and interzooidal avicularia; B, semicircular orifice with a pair of condyles and suboral avicularium with serrated rostral tip; C, close-up zooids with three spines; D, mandible of interzooidal avicularium showing dark brown sclerite (taken with Nikon D100 attached to streomicroscope Carl Zeiss SV6); E, interzooidal avicularia showing intact mandible. Scale bars $=0.5 \mathrm{~mm}(\mathrm{~A}, \mathrm{C}, \mathrm{E}), 0.1 \mathrm{~mm}(\mathrm{~B})$.

Celleporaria brunnea: Soule and Soule, 1973, p. 601, fig. 79; Banta, 1980, p. 396, fig. 24, 103; Soule et al., 1995, p. 267, pl. 101A-C.

Material examined. Tongyeong Marine Ranch, 29 Aug. 2004 (J.E. Seo) by SCUBA diving from $10-20 \mathrm{~m}$ in depth.

Substratum. Aquaculture steel cages.

Description. Colony encrusting substrata, forming coarse brown or gray incrustation or rising to form irregular cylindrical mass. Zooecia heaped, erratically oriented, 0.33-0.42 $\mathrm{mm}$ wide, $0.42-0.53 \mathrm{~mm}$ long, interzooidal boundaries indistinct, with more than ten areolar pores. Orifice semicircular, with usually two spines, sometimes three when spine presents, with almost straight proximal border having midline notch, bounded by horizontal, shelflike condyles that almost meet in center, also with a pair of small lateral condyles. Secondary peristome with psuedosinus beside low umbo bearing a small, raised avicularum with serrated rostral end. Large interzooidal avicularia scattered, with large palate; mandible with large spade shaped brown reinforcing sclerite 

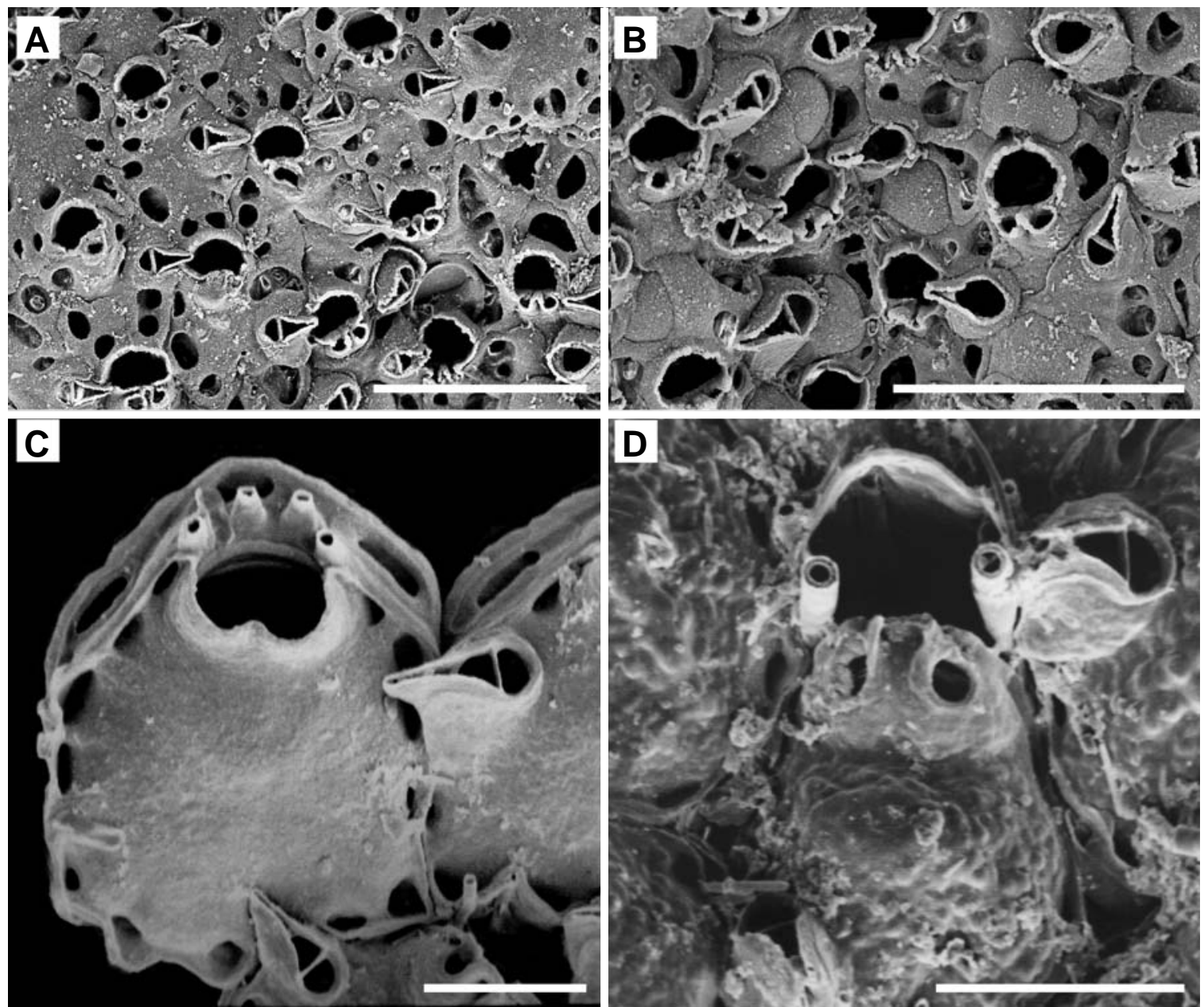

Fig. 8. Exochella tricuspis (Hincks, 1881). A, arrangement of zooids with areolar pores; B, ovicellate zooids heavily calcified; C, periancestrular young zooid with four spines; D, close-up zooid with two spines. Scale bars=0.5 mm (A, B), $0.1 \mathrm{~mm}(C, D)$.

in midline, narrowed at tip. Ovicell, hyperstomial, hoodshaped, covered frontally by secondary calcification.

Remarks. This species is very characteristic of having brown sclerite of mandible. Therefore, the specimens from Maldo described and figured by Seo and Rho (1989) under this name may belong to another species. This species is the one of the commonest species in California and Baja California waters (Soule et al., 1995), so it is considered to be the introduced species from eastern Pacific Ocean.

Distribution. Pacific including Korea (South Sea).

\section{Celleporaria wakayamensis (Okada and Mawatari, 1938)}

Material examined. Gaerinyeo Island, Gageodo Island, 13 Aug. 1998 (J.E. Seo) by SCUBA diving from 18-23 m in depth.

Substratum. Unknown.

Remarks. The Yellow Sea is added in the distribution of this species.

Distribution. Korea (South Sea, Jeju-do and Yellow Sea) and Japan.

Family Exochellidae Bassler, 1935

Genus Escharoides Milne-Edwards, 1836

\section{Escharoides excavata (MacGillivray, 1860)}

Material examined. Seogwipo Breakwater, 2 Aug. 1970 (B.J. Rho); Jin-ri, Deokjeokdo Island, 16 Oct. 1985 (H.S. Choi); Bakdeungdo Island, Sacheon, 13 Jun. 2000 (J.E. Seo); Taedo Island, Tongyeong, 28 Jun. 2006 (J.E. Seo); Bongdo Island, Tongyeong, 28 Jun. 2006 (J.E. Seo); Daejangdudo Island, Tongyeong, 28 Jun. 2006 (J.E. Seo).

Substratum. Stones.

Remarks. This species is a fouling bryozoan collected from the anchors and fish traps.

Distribution. Pacific including all coasts of southern Korea, 
and Indian.

Genus ${ }^{1 *}$ Exochella Jullien, 1888

2*Exochella tricuspis (Hincks, 1881) (Fig. 8)

Mucronella tricuspis Hincks, 1881, p. 125.

Exochella areolata Okada and Mawatari, 1937, p. 440, pl.

11, figs. 3-5, text-fig. 3; Rho and Lee, 1980, p. 119.

Exochella tricuspis: Brown, 1952, p. 289; Powell, 1967, p. 312; Uttley and Bullivant, 1971, p. 45; Gordon, 1984, p.

71, pl. 24, A-C; Hayward, 1991, p. 310, fig. 4C, D.

Material examined. Sinsido Island and Jangjado Island, Gogunsan Islands, 27 Jul. 1980 (B.J. Rho and K.H. Lee); Seogwipo, 22 May 1982 (J.I. Song); Mipo, 23 Aug. 2003. Substratum. Seaweeds.

Description. Colony encrusting seaweeds, unilamellar, forming circular patch. Zooecia $0.25-0.29 \mathrm{~mm}$ wide, $0.40-0.58 \mathrm{~mm}$ long, hexagonal, trapezoid, distinct, separated by grooves in young colony, later obscured by heavy calcification. Frontal wall smooth with about ten large, widely spaced areolar pores. Primary orifice transversely oval, obscured by peristome; a pair of indentations in form of rounded $\mathrm{W}$ appear in developing peristome, then sealed off distally by fusion of incurved edges of indentation, leaving a pair of peristomial spiramina in form of narrow shafts leading to compensation space beneath. Oral spines four in ancestrula and periancesctular zooids, two or three spines in autozooids and mature zooids. Single or a pair of avicularia from areolae proximal to orifice on frontal wall, raised at rostral tip, with acute rostrum, directed laterally or obliquely, with complete pivot bar. Ovicell smooth, at first recumbent on distal zooid, later completely immersed by frontal calcification of that zooid and detectable only as bulge of frontal wall.

Remarks. Exochella areolata Okada and Mawatari, 1937 which was reported as a new species by Okada and Mawatari (1937) is considered to be synonymized into E. tircuspis in having conical projection characteristic to this new species. The specimen described and illustrated from South Australia seems to be young colony showing three spines and distinct zooecial boundaries, whereas our specimes show the indistinct zooecial boundaries and ovicellate zooids.

Distribution. Korea(Yellow Sea), Japan and southern Pacific.

Infraorder Lepraliomorpha Gordon, 1989

Superfamily Smittinoidea Levinsen, 1909

Family Smittinidae Levinsen, 1909

Genus Parasmittina Osburn, 1952

Parasmittina contraria Seo, 1993

Material examined. Seogwipo, 2 Aug. 1972 (B.J. Rho); Mipo,
15 Jul. 1974 (B.J. Rho); Mipo, 25 Apr. 1975 (B.J. Rho); Moseulpo, 18 Jun. 1985 (J.E. Seo); Seongsanpo, 5 Nov. 2000 (J.I. Song) by SCUBA diving from $20 \mathrm{~m}$ in depth; Gaerinyeo Island, Gageodo Island, 13 Aug. 1998 (J.E. Seo) by SCUBA diving from $18-23 \mathrm{~m}$ in depth.

Substratum. Unknown.

Remarks. This species is endemic to Jejudo Island waters and Geojedo Island, South Sea so far. Gageodo Island of the Yellow Sea is newly added to the fauna of P. contraria herein. However, Gageodo Island is located in the farthest westsouthern of the Yellow Sea which is strongly affected by the Kuroshio Warm Current. It is considered that $P$. contraria seems to be a warm temperate or subtropical species. This species is a fouling bryozoan collected from fishing nets.

Distribution. Korea (South Sea, Jeju-do and Yellow Sea).

\section{Parasmittina crosslandi (Hastings, 1930)}

Material examined. Gaerinyeo Island, Gageodo Island, 13 Aug. 1998 (J.E. Seo) by SCUBA diving from $18-23 \mathrm{~m}$ in depth.

Remarks. The Yellow Sea is newly added to the distribution of this species in addition to Jejudo Island waters.

Distribution. Pacific including Korea (Jeju-do and Yellow Sea).

Genus Smittoidea Osburn, 1952

Smittoidea pacifica Soule and Soule, 1973

Material examined. Gaerinyeo Island, Gageodo Island, 13 Aug. 1998 (J.E. Seo) by SCUBA diving from 18-23 $\mathrm{m}$ in depth.

Substratum. Unknown.

Remarks. This species is a fouling bryozoan collected from fishing nets.

Distribution. Pacific including Japan and Korea (East Sea, Jeju-do and Yellow Sea).

\section{Smittoidea prolifica Osburn, 1952}

Material examined. Wolseong, 5 Feb. 1985; Maldo Island, 10 Jul. 1986; Gaerinyeo Island, Gageodo Island, 13 Aug. 1998 (J.E. Seo) by SCUBA diving from 18-23 $\mathrm{m}$ in depth; Hangaechang in Munseom Island, Jeju-do, 26 Feb. 2003 (J.E. Seo) by SCUBA diving from $28 \mathrm{~m}$ in depth.

Substratum. Unknown.

Remarks. The zooecia of this species usually have two to four spines, however five spines are found in only one zooecium in the colony which is collected from Munseom Island. Distribution. Pacific including Japan and all coasts of south-

\footnotetext{
$1 *$ 꽈리이끼벌레 (신칭), ${ }^{2 *}$ 삼첨 꽈리이끼벌레 (신칭)
} 
ern Korea.

Family Bitectiporidae MacGillivray, 1895

Genus Codonellina Bassler, 1934

Codonellina montferrandii (Audouin, 1826)

Material examined. Beomseom Island, Jeju-do, 22 Oct. 1991 (J.I. Song) by SCUBA diving; Chaguido Island, 8 Jun. 2000 (J.I. Song); Beomseom Island, Jeju-do, 3 Nov. 2000 (J.I. Song) by SCUBA diving from $30 \mathrm{~m}$ in depth; Marado Island, 4 Nov. 2000 (J.I. Song) by SCUBA diving from 30 $\mathrm{m}$ in depth; Husuwolsan light house in Seodo Island, Geomundo Island, 10 Nov. 1991 (J.K. Park) by SCUBA diving from 15-20 m in depth; Wadal-ri, Ulreungdo Island, 7 Aug. 1992; Baekdo Island, Geomundo Island, 28 Mar. 2002 (J.J. Sim) by SCUBA diving from $20 \mathrm{~m}$ in depth; Gaerinyeo Island, Gageodo Island, 13 Aug. 1998 (J.E. Seo) by SCUBA diving from 18-23 $\mathrm{m}$ in depth.

Substratum. Sponges, hydrozoans, other bryozoan (Watersipora sp.) and seaweeds.

Distribution. Pacific including Japan and Korea (South Sea, Jeju-do and Yellow Sea), and Indian.

\section{Codonellina parviaviculata Rho and Seo, 1988}

Material examined. Ohak-ri, Geumodo Island, 5 Aug. 1983 (J.I. Song); Samcheonpo, 20 Jul. 1984 (J.E. Seo); Saryangdo Island, 5 Jul. 1993 (J.E. Seo) from $5 \mathrm{~m}$ in depth; Uldo Island, Tongyeong, 27 Jun. 2006 (J.E. Seo); Taedo Island, Tongyeong, 28 Jun. 2006 (J.E. Seo).

Substratum. Stones, other bryozoan and shells.

Remarks. This species is endemic to Korean waters so far, and the South Sea is newly added in its distribution herein. This species is a fouling bryozoan collected from fishing nets.

Distribution. Korea (East Sea, South Sea and Yellow Sea).

Genus Schizomavella Canu and Bassler, 1934

\section{Schizomavella acuta Osburn, 1952}

Material examined. Tonggumi, Ulreungdo Island, 8 Aug. 1992 (J.K. Park) by SCUBA diving.

Substratum. Unknown.

Remarks. The East Sea is recorded as new distribution of this species.

Distribution. Pacific including Japan and Korea (East Sea and South Sea), and Indian.

Family Watersiporidae Vigneaux, 1949

Genus Watersipora Neviani, 1895

Watersipora platypora Seo, 1999
Material examined. Beomseom Island, Jeju-do, 3 Nov. 2000 (J.I. Song) by SCUBA diving from $30 \mathrm{~m}$ in depth; Seongsanpo, 5 Nov. 2000 (J.I. Song) by SCUBA diving from 20 $\mathrm{m}$ in depth; Seongsanpo, 9 Jun. 2001 (J.I. Song) by SCUBA diving from $20 \mathrm{~m}$ in depth.

Substratum. Other bryozoan.

Remarks. This species is endemic to Korean waters so far.

Distribution. Korea (South Sea and Jeju-do).

\section{Watersipora subtorquata (D'Orbigny, 1842)}

Material examined. Gunghang, 9 Jul. 1998 (S. Shin); Gyeokpo, 9 Jul. 1998 (S. Shin); Mohang, 9 Jul. 1998 (S. Shin); Daecheon, 10 Jul. 1998; Hangmakjung, Geojedo Island, 14 Jul. 1999 (S. Shin); Yunpo, Geojedo Island, 14 Jul. 1999 (S. Shin); Janghang, Geojedo Island, 15 Jul. 1999 (S. Shin); Sari and Gonchon, Heuksando Island, 11 Aug. 1999 (J.E. Seo); Jin-ri, Heuksando Island, 12 Aug. 1999 (J.E. Seo); Changpo 2-ri, Gyeongjeong, 13 1999, Sep. 1999 (J.E. Seo); Sobongdae, Yangpo, 14 Sep. 1999 (Y.H. Gong); Balsan 1-ri, 15 Sep. 1999 (J.E. Seo); Yonguimeori, Daejin, 16 Sep. 1999 (J.E. Seo); Adudo Island, Sacheon, 12 Jun. 2000, (J.E. Seo); Gaeseom Island, Keungaeseom Island and Hyanggido Island, Sacheon, 14 Jun. 2000 (J.E. Seo); Beomseom Island, Jejudo, 3 Nov. 2000 (J.I. Song) by SCUBA diving from $30 \mathrm{~m}$ in depth; Chaguido Island, 6 Jun. 2000 (J.I. Song) by SCUBA diving from $25 \mathrm{~m}$ in depth; Jungpyeon in Gollido Island, 23 Jul. 2001 (J.E. Seo); Mijo-ri, Namhaedo Island, 2 Nov. 2002 (Y.H. Gong); Sangju-ri, Namhaedo Island, 2 Nov. 2002 (J.E. Seo) from test panels; Gaerinyeo Island, Gageodo Island, 13 Aug. 1998 (J.E. Seo) by SCUBA diving from 18-23 $\mathrm{m}$ in depth; Sangju-ri, Namhaedo Island, 3 Dec. 2002 (J.E. Seo) from test panels; Sangju-ri, Namhaedo Island, 17 Feb. 2003 (J.E. Seo) from test panels; Tongyeong Marine Ranch, 29 Aug. 2004 (J.E. Seo) by SCUBA diving from 10-20 m in depth; Chukdo Island, Tongyeong, 26 Jun. 2006 (J.E. Seo); Godo Island, Tongyeong, 27 Jun. 2006 (J.E. Seo); Uldo Island, Tongyeong, 26 Jun. 2006 (J.E. Seo); Taedo Island, Tongyeong, 28 Jun. 2006 (J.E. Seo); Yudo Island, Tongyeong, 28 Jun. 2006 (J.E. Seo); Daemangjado Island, Tongyeong, 29 Jun. 2006 (J.E. Seo); Hodo Island, Tongyeong, 30 Jun. 2006 (J.E. Seo); Oehoenggyeondo Island and Burando Island, Boryeong, 26 Jun. 2007 (J.E. Seo); Sohoenggyeongdo Island, Gogunsan Islands, 8 Jun. 2007 (J.E. Seo); Daehyeongjedo Island, Wido Island, 13 Jun. 2007 (J.E. Seo); Sudo Island, Boryeong, 27 Jun. 2007 (J.E. Seo).

Substratum. Ropes hanging on the wharf, shells, plastics, seaweeds, sponges, cement test panels, worm tubes, stones and tunicates.

Remarks. This species is the commonest fouling bryozoan as well as the commonest in intertidal zone of Korean waters. 

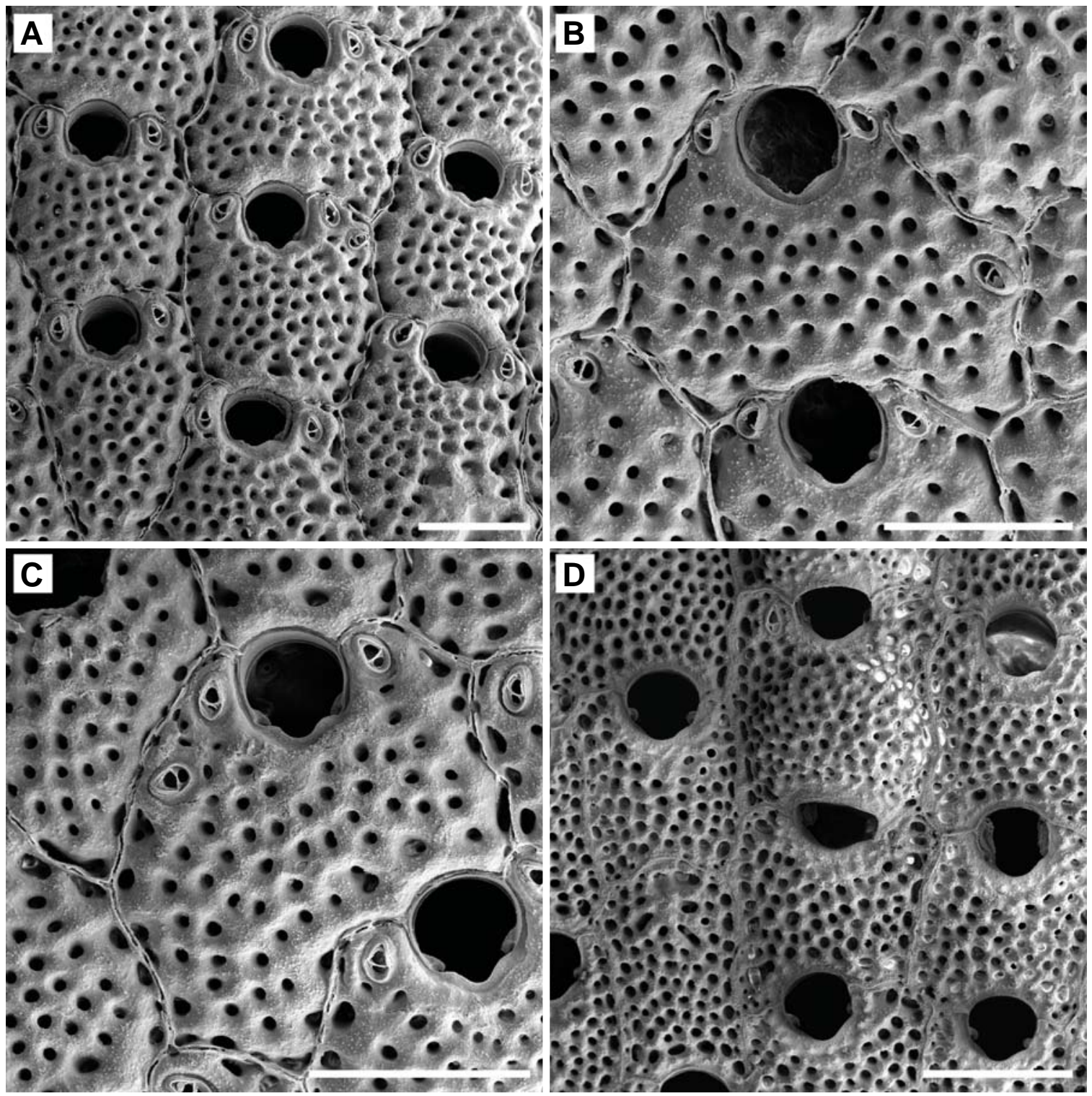

Fig. 9. Calyptotheca parcimunita Harmer, 1957. A, arrangement of zooids; B, close-up zooid with three avicularia; C, another zooids with three avicularia; $D$, ovicellate zooids. Scale bars $=0.3 \mathrm{~mm}(A-C), 0.5 \mathrm{~mm}(D)$.

\section{Distribution. Cosmopolitan.}

Superfamily Schizoporelloidea Jullien, 1883

Family Schizoporellidae Hincks, 1877

Genus Schizoporella Hincks, 1877

\section{Schizoporella unicornis (Johnston, 1847)}

Material examined. Byeonsan beach, 8 Apr. 1993 (J.E. Seo); Daecheon, 10 Jul. 1998 (S. Shin); Yeongheungdo Island, 23 Jul. 1998 (S. Shin); Heungnam, Geojedo Island, 13 Jul. 1999 (S. Shin); Mipo, 14 Jul. 1999 (S. Shin); Gabae, Geojaedo Island, 14 Jul. 1999 (S. Shin); Hyangmyeongchon, Geojedo
Island, 15 Jul. 1999; Janghang, Geojedo Island, 15 Jul. 1999 (S. Shin); Yunpo, Geojedo Island, 14 Jul. 1999 (S. Shin); Sari, Heuksando Island, 11 Aug. 1999 (J.E. Seo): Mangbuseok, Gageodo Island, 16 Aug. 1999 (J.E. Seo); Balsan 1-ri, 15 Sep. 1999 (J.E. Seo); Mokdo Island, Sacheon, 12 Jun. 2000 (J.E. Seo); Keungaeseom Island and Hyanggiseom Island, Sacheon, 14 Jun. 2000 (J.E. Seo); Mijo-ri, Namhaedo Island, 2 Nov. 2002 (Y.H. Gong); Godo Island, Tongyeong, 27 Jun. 2006 (J.E. Seo); Uldo Island, Tongyeong, 27 Jun. 2006 (J.E. Seo); Junghangdo Island, Tongyeong, 27 Jun. 2006 (J.E. Seo); Bongdo Island, Tongyeong, 28 Jun. 2006; Taedo Island, Tongyeong, 28 Jun. 2006 (J.E. Seo); Hodo Island, Tongyeong, 
30 Jun. 2006 (J.E. Seo); Daehyeungjaedo Island, Wido, 13 Jun. 2007 (J.E. Seo); Sudo Island, Boryeong, 27 Jun. 2007 (J.E. Seo).

Substratum. Shells, stones, tunicates, barnacles and boat's hull.

Remarks. This species is a fouling bryozoan.

Distribution. Pacific including Japan and Korea (East Sea, South Sea and Yellow Sea), Atlantic and Arctic.

Family Lanceoporidae Harmer, 1957

Genus Calyptotheca Harmer, 1957

$1 *$ Calyptotheca parcimunita Harmer, 1957 (Fig. 9)

Calyptotheca parcimunita Harmer, 1957, p. 1015, pl. 68, figs. $12,13$.

Material examined. Mipo, 13 Jul. 1974 (B.J. Rho); Saryangdo Island, 5 Jul. 1993 (J.E. Seo) from $5 \mathrm{~m}$ in depth.

Substratum. Shells and anthozoans.

Description. Colony encrusting substrata. Zooecia arranged regularly, separated by distinct grooves, nearly square, 0.47 $0.66 \mathrm{~mm}$ wide, 0.69-0.67 mm long, somewhat longer than wide, or irregular pentagonal, flat with evenly scattered minute pores and larger areolar pores. Orifice about as long as wide, with a pair of strong condyles forming large and rounded v-shaped sinus. A pair of avicularia on distal half of lateral to orifice, very narrow and acute, minute, directed distally. Sometimes, one more avicularium found near orifice or near to areolar pore. Ovicell, large, perforate as in frontal wall, endooecial in proceeding zooecium.

Remarks. This species is characteric of a pair of minute and acute avicularia on the distal half of lateral to orifice, compared with the other species belonging to Calyptotheca.

Distribution. Southewestern Pacific including Korea (South Sea), and Indian.

\section{Calyptotheca symmetrica (Ortmann, 1890)}

Material examined. Mipo, 15 May 1980 (B.J. Rho); Chujado Island, 25 May 1987 (J.E. Seo) from 100 m in depth; Gimyeong, 15 Jul. 1991 (J.E. Seo); Gudo Island, Geojedo Island, 6 Feb. 1996 (J.E. Seo); Marine Institute in Gaebae, Geojedo Island, 8 Jul. 1996 (J.E. Seo); Sobongdae, Yangpo, 14 Sep. 1999 (J.E. Seo); Chaguido Island, 17 Aug. 2002 (J.I. Song) by SCUBA diving; Daejangdudo Island, Tongyeong, 28 Jun. 2006 (J.E. Seo).

Substratum. Stones, shells, seaweeds, anthozoans and worm tubes.

Remarks. This is a fouling bryozoan collected from tires hanging on the wharf.
Distribution. Korea (South Sea and Jeju-do) and Japan.

\section{Calyptotheca wasiensis (Waters, 1909)}

Material examined. Dongseom Island, Maemuldo Island, 11 Apr. 2002 (J.E. Seo); Chaguido Island, 8 Jun. 2000 (J.I. Song); Gaerinyeo Island, Gageodo Island, 13 Aug. 1998 (J.E. Seo) by SCUBA diving from 18-23 $\mathrm{m}$ in depth.

Substratum. Tunicates.

Distribution. Pacific including Korea (South Sea, Jeju-do and Yellow Sea), and Indian.

Family Cryptosulidae Vigneaux, 1949

Genus Cryptosula Canu and Bassler, 1925

Cryptosula pallasiana (Moll, 1803)

Material examined. Yunpo, Geojedo Island, 14 Jul. 1999 (S. Shin); Hangmakjung, Geojedo Island, 14 Jul. 1999 (S. Shin); Sa-ri, Heuksando Island, 11 Aug. 1999 (J.E. Seo); Masan, Balsan, 15 Sep. 1999 (J.E. Seo).

Substratum. Stones and shells.

Remarks. This species is newly found for the first time from the Yellow Sea and a fouling bryozoan found from boat's hull and piece of clothing.

Distribution. Cosmopolitan. In Korea, it is found from the East Sea, South Sea and Yellow Sea.

Family Microporellidae Hincks, 1879

Genus Fenestrulina Jullien, 1888

Fenestrulina malusii (Audouin, 1826)

Material examined. Cheokdo Island, Wando Island, 13 Jun. 1999 (Y.H. Gong); Solseom Island and Adudo Island, Sacheon, 12 Jun. 2000 (J.E. Seo); Jungpyeon in Gollido, 23 Jul. 2001 (J.E. Seo); Gaerinyeo Island, Gageodo Island, 13 Aug. 1998 (J.E. Seo) by SCUBA diving from 18-23 $\mathrm{m}$ in depth; Hodo Island, Tongyeong, 30 Jun. 2006 (J.E. Seo); Godo Island, Tongyeong, 27 Jun. 2006 (J.E. Seo); Uldo Island, Tongyeong, 27 Jun. 2006 (J.E. Seo); Junghangdo Island, Tongyeong, 27 Jun. 2006; Hahangdo Island, Tongyeong, 27 Jun. 2006; Daejangdudo Island, Tongyeong, 28 Jun. 2006 (J.E. Seo); Yujado Island, Tongyeong, 29 Jun. 2006 (J.E. Seo); Daemangjado Island, Tongyeong, 29 Jun. 2006 (J.E. Seo); Jangdo Island, Tongyeong, 29 Jun. 2006 (J.E. Seo); Mongdeokdo Island and Sudo Island, Boryeong, 27 Jun. 2007 (J.E. Seo).

Substratum. Seaweeds and bivalve shells.

Remarks. This species is a fouling bryozoan found from ropes hanging on the wharf.

$1 *$ 작은조두체은협이끼벌레 (신칭) 

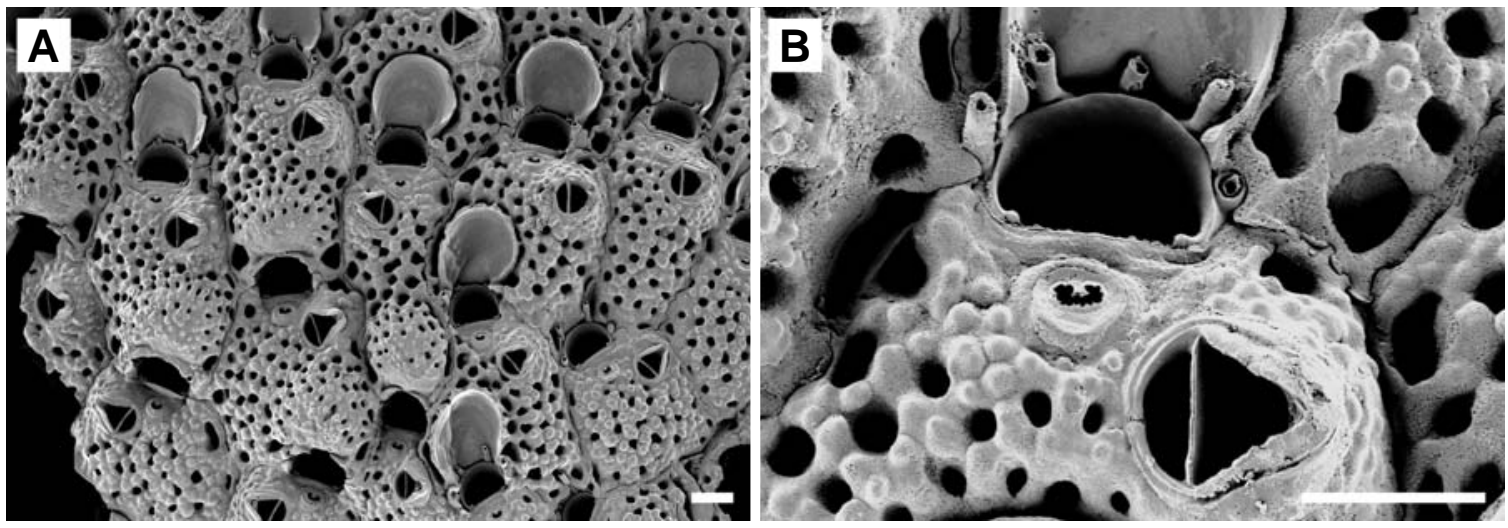

Fig. 10. Microporella borealis Suwa and Mawatari, 1998. A, arrangement of zooids; $B$, close-up zooid showing five spines, ascopore and avicularium. Scale bars $=0.1 \mathrm{~mm}(\mathrm{~A}, \mathrm{~B})$.

\section{Distribution. Cosmopolitan.}

\section{Fenestrulina mutabilis (Hastings, 1932)}

Material examined. Uldo Island, Tongyeong, 27 Jun. 2006 (J.E. Seo).

Substratum. Unknown.

Remarks. This species is distinguishable from $F$. malusii showing smaller zooid and broader basal membranous part. Distribution. Pacific including Japan and all coasts of southern Korea, and Atlantic.

Genus Microporella Hincks, 1877

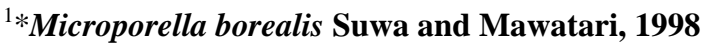

(Fig. 10)

Microporella borealis Suwa and Mawatari, 1998, p. 902, fig. 3A-M.

Material examined. Geomeunyeo Island, Ocheon, 6 Apr. 2003 (Y.H. Gong and K.B. Lee) by SCUBA diving from 5 $\mathrm{m}$ in depth.

Substratum. Oyster shells.

Description. Colony encrusting substrata. Zooecium 0.25$0.34 \mathrm{~mm}$ wide, $0.39-0.52 \mathrm{~mm}$ long, hexagonal or somewhat irregular in shape. Frontal wall slightly convex, coarsely granular, with evenly distributed pores. Orifice semicircular, with serrated proximal lip and prominent condyles at corners. Oral spines four or five. When ovicell presents, two or three middle spines hidden by ovicell and two lateral only seen. Ascopore close to proximal lip of orifice, separated from it by distance equivalent to about one-third of orifice length, crescentic, with denticulate edge, raised on cup-shaped thin prominence, proximal part of which sometimes develops into umbo. Avicularium single, on right or left, proximolateral to ascopore. Avicularian chamber fairly large occupying 1/4 $-1 / 3$ of frontal wall; rostrum short triangular, raised at tip, directed laterally. Ovicell subimmersed, coarsely granular, perforated with a number of pores which generally smaller than pores of frontal wall, perforation rare near top and proximally.

Remarks. Our specimen was collected from oyster shells, while Japanese one from scallop shells. Korean specimen shows the difference from Japanese one in having no cribrate plate at bottom of pores. Suwa and Mawatari described and illustrated that ovicellate zooids have no oral spines, however the authors consider that the oral spines just were hidden by the ovicell.

Distribution. Korea (Yellow Sea) and Japan.

Family Calwellidae MacGillivray, 1887

Genus Onchoporella Busk, 1884

Onchoporella selenoides Ortmann, 1890

Material examined. Gaerinyeo Island, Gageodo Island, 13 Aug. 1998 (J.E. Seo) by SCUBA diving from 18-23 m in depth; Hangdo Island, Tongyeong, 29 Jun. 2006 (J.E. Seo).

Substratum. Unknown.

Remarks. This species is newly found from the Yellow Sea. Distribution. Korea (South Sea, Jeju-do and Yellow Sea) and Japan.

Family Petraliellidae Harmer, 1957

Genus Hippopetraliella Stach, 1936

Hippopetraliella magna (D’Orbigny, 1852)

Material examined. Marado Island, 4 Nov. 2000 (J.I. Song) by SCUBA diving from $30 \mathrm{~m}$ in depth; Marado Island, 22 Feb. 2001 (J.I. Song) by SCUBA diving from $18 \mathrm{~m}$ in depth.

\footnotetext{
1*냉수소공이끼벌레 (신칭)
} 

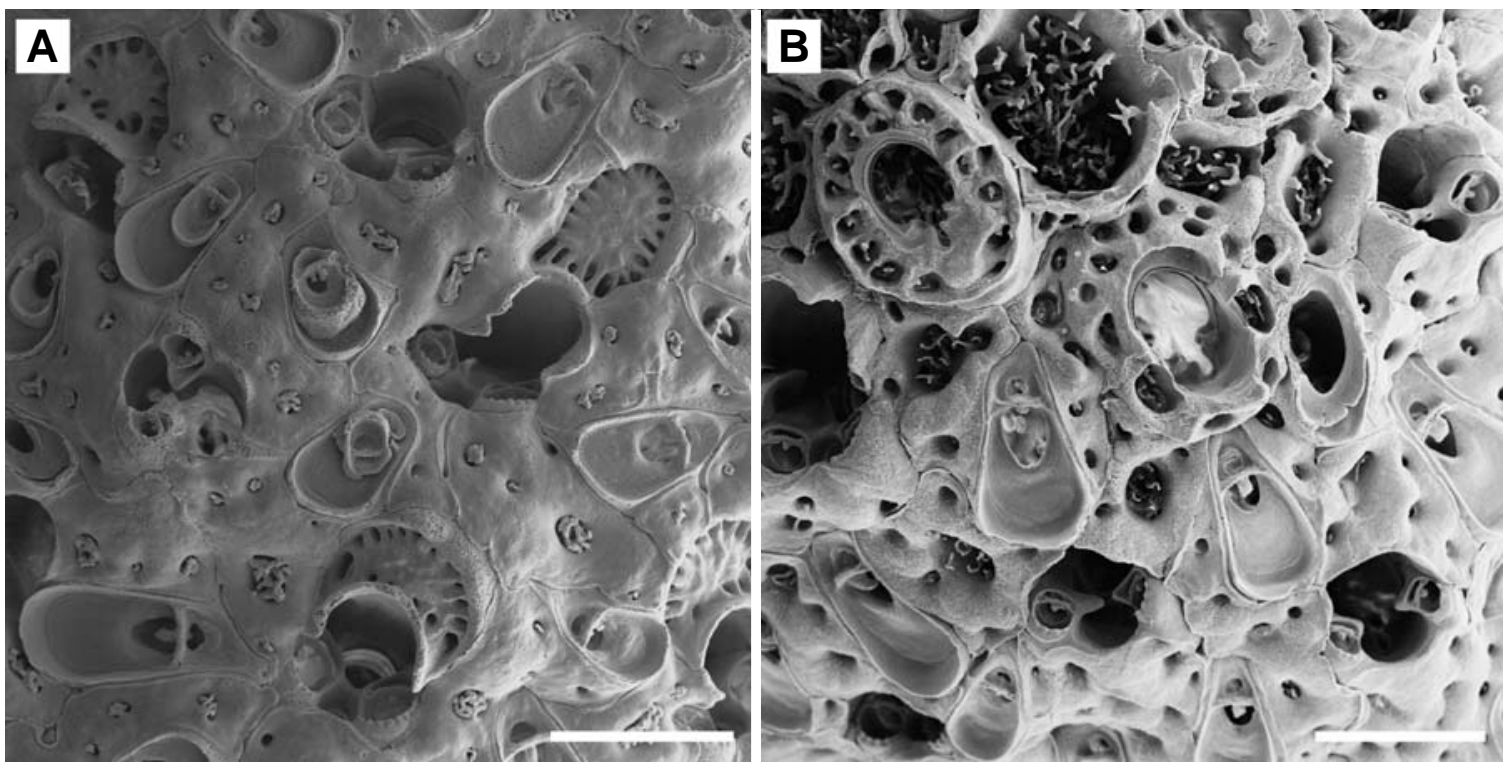

Fig. 11. Celleporina rostellata Harmer, 1957. A, irregular arrangement of ovicellate zooids and variable interzooidal avicularia in size and shape; $B$, zooids showing orifice and a pair of suboral avicularia. Scale bars $=0.2 \mathrm{~mm}(A, B)$.

Substratum. Unknown.

Distribution. Cosmopolitan. In Korea, it is found from the South Sea and Jeju-do.

Genus Mucropetraliella Stach, 1936

\section{Mucropetraliella mucroaviculata (Okada and}

Mawatari, 1938)

Material examined. Seongsanpo, 9 Jun. 2000 (J.I. Song).

Substratum. Unknown.

Distribution. Korea (Jeju-do) and Japan.

Family Crepidacanthidae Levinsen, 1909

Genus Crepidacantha Levinsen, 1909

Crepidacantha poissoni (Audouin, 1826)

Material examined. Gaerinyeo Island, Gageodo Island, 13 Aug. 1998 (J.E. Seo) by SCUBA diving from $18-23 \mathrm{~m}$ in depth.

Substratum. Unknown.

Remarks. This species is newly collected from the Yellow Sea.

Distribution. Cosmopolitan. In Korea, it is found from the South Sea and Yellow Sea.

Family Lacernidae Jullien, 1888

Genus Arthropoma Levinsen, 1909

Arthropoma cecilii (Audouin, 1826)

Material examined. Biyangdo Island, 6 Feb. 1986 (J.E. Seo);
Chukdo Island, Tongyeong, 26 Jun. 2006 (J.E. Seo). Substratum. Scallop shells.

Distribution. Cosmopolitan. In Korea, it is found from the South Sea and Jeju-do.

Superfamily Celleporoidea Lamouroux, 1821

Family Celleporidae Lamouroux, 1821

Genus Celleporina Gray, 1848

${ }^{1 *}$ Celleporina rostellata Harmer, 1957 (Fig. 11)

Celleporina rostellata Harmer, 1957, p. 907, pl. 62, figs.

18, 19; Hayward and Ryland, 1995, p. 565, figs. 14F, 15A, B.

Material examined. Manjaedo Island, 23 Aug. 1988 (J.E. Seo) from $20 \mathrm{~m}$ in depth; 1-ri, Balsan, 15 Sep. 1999 (J.E. Seo).

Substratum. Fishing nets (40-50 m deep).

Description. Colony at first encrusting substrata, soon later forming nodules or cylinders. Zooecia smoothly calcified, closely packed causing irregular arrangement of zooids, 0.23-0.28 mm wide, 0.37-0.59 mm long. Frontal wall developing as reticulate circle with central opening. Primary orifice slightly longer than wide, with deep and $\mathrm{U}$-shaped sinus occupying half of its total width, with a pair of condyles. Peristome surrounding orifice and incorporating a pair of proximo-lateral, suboral avicularia with oval, vertically orientated rostrum, distal rim finely denticulate; medio-proximal rim deeply notched, opposite proximo-lateral edge devel-

\footnotetext{
1*부리조두체가지이끼벌레 (신칭)
} 

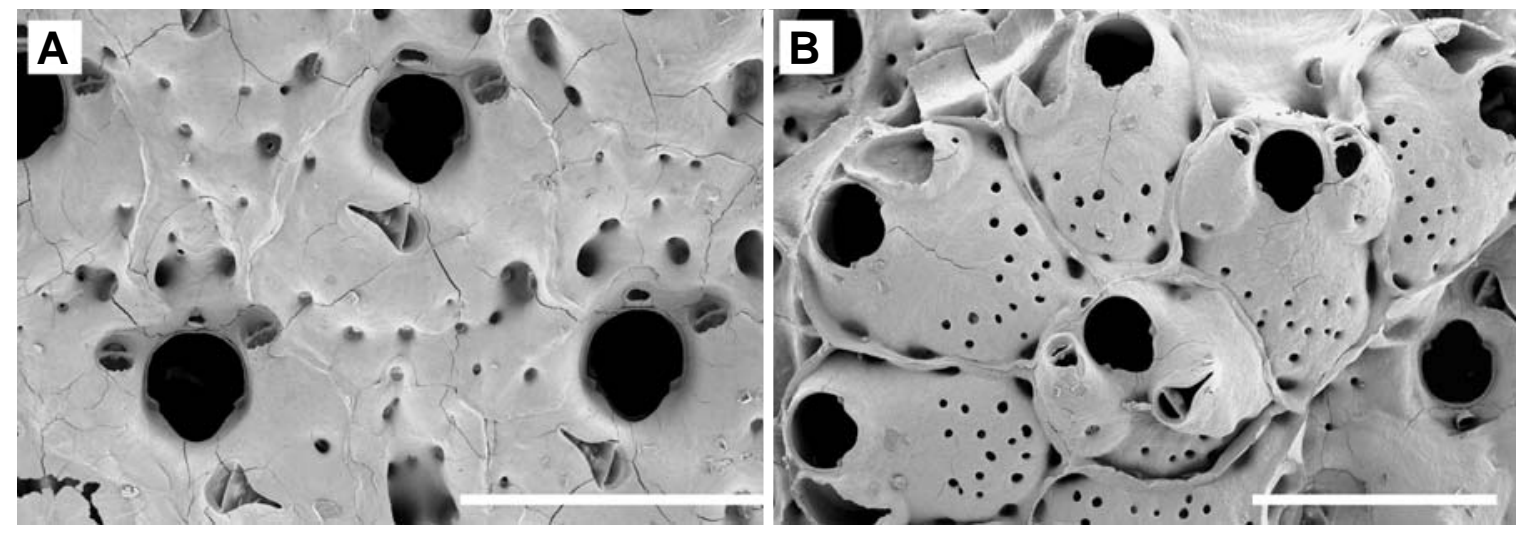

Fig. 12. Buffonellaria acutirostris Seo and Gong, 2006. A, rare zooid showing a pair of avicularia lateral to orifice; $B$, ancestrula and periancestrular zooids. Scale bars $=0.5 \mathrm{~mm}(A, B)$.

oped as thickened umbo. Avicularia faces laterally; its proximal edge produced as a sub-triangular process projecting above peristomial notch. Interzooidal avicularia very frequent, varying in size; its rostrum broadened distally and deeply cupped; crossbar complete; palate with an extensive foramen. Ovicell hemispherical, frontally showing radiating ribs formed by two rows of pores.

Remarks. This species is a fouling bryozoan.

Distribution. Pacific, including Korea (East Sea).

\section{Celleporina porosissima (Okada, 1923)}

Material examined. Chuksa, Gampo, 2 Jul. 1998 (S. Shin); Sa-ri and Gonchon, Heuksando Island, 11 Aug. 1999 (J.E. Seo); Dwitdaemok, Heuksando Island, 12 Aug. 1999 (J.E. Seo); Changpo 2-ri, Gyeongjeong, 13 Sep. 1999 (J.E. Seo); Ulgi light house, 14 Sep. 1999 (J.E. Seo); Seuldo Island, Bangeojin, 14 Sep. 1999 (J.E. Seo); 1-ri, Balsan, 15 Sep. 1999 (J.E. Seo); Gyeongjeong, 17 Sep. 1999 (J.E. Seo); Gaerinyeo Island, Gageodo Island 13 Aug. 1998 (J.E. Seo) by SCUBA diving from $18-23 \mathrm{~m}$ in depth; Taedo Island, Tongyeong, 28 Jun. 2006 (J.E. Seo); Bongdo Island, Tongyeong, 28 Jun. 2006 (J.E. Seo); Daemangjado Island, Tongyeong, 29 Jun. 2006 (J.E. Seo); Daehyeungjedo Island, Wido Island, 13 Jun. 2007 (J.E. Seo); Oehoenggyeondo Island, Boryeong, 26 Jun. 2007.

Substratum. Stones, seaweeds and shells.

Remarks. This species is a fouling bryozoan found from fishing nets mostly.

Distribution. All coasts of southern Korea and Japan.

Genus Buffonellaria Canu and Bassler, 1917

Buffonellaria acutirostris Seo and Gong, 2006 (Fig. 12)

Buffonellaria acutirostris Seo and Gong, 2006, p. 13, fig. 2.
Remarks. The specimen from Munseom Island reported by Seo and Gong (2006) shows ancestrula and a pair of avicularia lateral to orifice.

Distribution. Korea (Jeju-do).

Family Phidoloporidae Gabb and Horn, 1862

Genus Iodictyum Harmer, 1933

Iodictyum axillare (Ortmann, 1890)

Material examined. Beomseom Island, Jeju-do, 3 Nov. 2000 (J.I. Song) by SCUBA diving from $30 \mathrm{~m}$ in depth; Seongsanpo, 5 Nov. 2000 (J.I. Song) by SCUBA diving from 20 $\mathrm{m}$ in depth.

Substratum. Unknown.

Remarks. This species is easily recognizable because of its red colony.

Distribution. Korea (South Sea and Jeju-do) and Japan.

Genus Phidolopora Gabb and Horn, 1862

Phidolopora pacifica (Robertson, 1908)

Material examined. Chujado Island, 25 May 1987; Marine Institute in Gaebae, Geojedo Island, 10 Jul. 1996 (W.J. Lee); Seongsanpo, 5 Nov. 2000 (J.I. Song) by SCUBA diving from $20 \mathrm{~m}$ in depth; Chaguido Island, 6 Jun. 2000 (J.I. Song) by SCUBA diving from $25 \mathrm{~m}$ in depth; Baekdo Island, Geomundo Island, 28 Mar. 2002 (J.J. Sim) by SCUBA diving from $20 \mathrm{~m}$ in depth; Budo Island, Tongyeong, 27 Jun. 2006 (J.E. Seo).

Substratum. Sponges.

Remarks. This is a fouling species collected from fish traps. Distribution. Pacific, including Japan and Korea (East Sea, South Sea and Jeju-do). 
Genus Reteporellina Harmer, 1933

Reteporellina denticulata (Busk, 1884)

Material examined. Munseom Island, Jeju-do, 26 Feb. 2003

(J.E. Seo) by SCUBA diving from $28 \mathrm{~m}$ in depth.

Substratum. Unknown.

Distribution. Cosmopolitan. In Korea, it is found from the East Sea and Jeju-do.

Family Unplaced ascophoran genus

Robertsonidra argentea (Hincks, 1881)

Material examined. Seogwipo, 13 Jul. 1979 (H.K. Kim).

Substratum. Seaweeds.

Distribution. Cosmopolitan. In Korea, it is found only from Jeju-do.

\section{DISCUSSION}

Two new species and eight new records from Korea are added in the Korean bryzoan fauna in the present study. Accordingly, a total of 113 species of cheilostomatous bryozoans are reported from South Korea waters. It is remarkable that twenty seven of 71 species reported in the present study were collected from Gageodo Island waters. Of which, Antropora tincta, Chaperia acanthia, Bugula dentata, Caberea boryi, Scrupocellaria maderensis, Steginoporella magnilabris, Thalamoporella lioticha, Integripelta meta, Celleporaria wakayamensis, Parasmittina contraria, $P$. crosslandi, Codonellina montferrandii, Calyptotheca wasiensis, Onchoporella selenoides and Crepidacantha poissoni of 15 species have been reported only from the South Sea or Jeju-do waters, or both Seas so far. The rest were found from the East Sea in addition to the South Sea and Jejudo Island waters. Gageodo Island located in the farthest westsouthern of the Yellow Sea is strongly affected by the Kuroshio Warm Current, thus it is likely that the fauna of marine invertebrates from Gageodo Island waters is similar to the fauna of South Sea or Jejudo Island waters. In terms of marine sponges, thirty four of 35 species from Gageodo Island waters also were found only from the South Sea and Jejudo Island waters (Sim and Kim, 2002) with exception of one species from the East Sea. The coincidental results from both bryozoans and sponges suggest that Gageodo Island waters rather belongs to Jejudo Island waters or the South Sea, not the Yellow Sea zoogeographically.

\section{ACKNOWLEDGEMENTS}

This work was supported by the Korea Research Foundation
Grant funded by the Korean Government (MOEHRD) (R052004-000-11065-0).

\section{REFERENCES}

Banta, W.C., 1980. Common intertidal invertebrates of the Gulf of California 24. Bryozoa (moss animals). Univ. Arizona Press, Tuison, Arizona, pp. 356-396.

Brown, D.A., 1952. The tertiary cheilostomatous Polyzoa of New Zealand. Br. Mus. Nat. Hist., Lond., pp. 1-145.

O'Donoghue, C.H. and E. O'Dodonhue, 1926. A second list of Bryozoa (Polyzoa) from the Vancouver Island region. Contr. Can. Biol. Fish., 3(3): 49-137, pls. 1-5.

Gong, Y.-H. and J.E. Seo, 2004. A taxonomic study on fouling bryozoans from Korea. Underwater Science and Technology, 5(1): 11-16 (in Korean).

Gordon, D.P., 1984. The marine fauna of New Zealand: Bryozoa: Gymnolaemata from the Kermadec Ridge. N. Z. Oceanogr. Inst. Mem., 91: 1-198.

Harmer, S.F., 1926. The Polyzoa of the Siboga Expedition Part II, Cheilostomata-Anasca, Siboga-Expeditie, 28b: 181-480.

Harmer, S.F., 1957. Polyzoa of the Siboga Expedition, part IV. Cheilostomata-Ascophora II. Siboga-Expeditie, 28d: 6411147, pls. 42-74.

Hastings, A.B., 1930. Cheilostomatous Polyzoa from the vicinity of the Panama Canal. Proc. Zool. Soc. Lond., 4: 697740.

Hastings, A.B., 1932. The Polyzoa with a note on and associated Hydroid. Br. Mus. Nat. Hist., Lond., Reports, 4(12): 398 460, pl. 1.

Hayward, P.J., 1991. Systematic studies on some Antactic and Subantarctic Ascophora (Bryozoa: Cheilostomata). Zool. J. Linn. Soc., 101: 299-335.

Hayward, P.J. and J.S. Ryland, 1995. Bryozoa from Heron Island, Great Barrier Reef. 2. Mem. Queensland Mus., 38(2): 533-573.

Hincks, R.T., 1881. Contributions towards a general history of the marine Polyzoa II. IV. foreign Membraniporina (second series). V. foreign Cheilostomata (miscellaneous). Ann. Mag. Nat. Hist., 5, 7: 147-161.

Hincks, T., 1884. Polyzoa of the Queen Charlotte Islands: preliminary notice of some species, pt.3. Ann. Mag. Nat. Hist., 5, 13: 49-58.

Liu, X.X., 1984. On the species of family Scrupocellidae collected form Chinese Seas. Stud. Mar. Sinica., (23): 257-308 (in Chinese).

Liu, X.X., 1991. A study on the anascan-cribrimorphan bryozoans from Nansha Islands of China. Res. J. Coll. Stud. Nansha Is., 5: 56-81 (in Chinese with English summary).

Liu, X.X., 1992. On the genus Membranipora (Anasca: Cheilostomata: Bryozoa) from South Chinese Seas. Raffles Bull. Zool., 40(1): 103-144.

Liu, X.X., X. Yin and J. Ma, 2001. Biology of marine fouling bryozoans in the coastal waters of China. Science Press, 
Beijing, China, pp. 1-860, pls. 82 (in Chinese with English abstracts).

Mawatari, S., 1952. Bryozoa of Kii peninsula, Publ. Seto Mar. Biol. Lab., 2(2): 261-288.

Mawatari, S., 1973. Studies on Japanese anascan Bryozoa 2. Division Scrupariina. Bull. Nat. Sci. Mus. Tokyo, 16(4): 605-624.

Mawatari, S. and S.F. Mawatari, 1980. Studies on Japanese anascan Bryozoa 5. Division Malacostege (3). Bull. Lib. Arts and Sci. Course, Sch. Med. Nihon Univ., 8: 21-114.

Mawatari, S. and S.F. Mawatari, 1986. Bryozoa-In the Japan research group of marine fouling organisms, Tokyo (ed.): study of marine fouling-identification of species-. KoseishaKoseikaku Tokyo, pp. 71-106 (in Japanese).

Okada, Y., 1923. On a collection of Bryozoa from the Straits of Corea. Annat. Zool. Jpn., 10(22): 215-234.

Okada, Y., 1929. Report of the biological survey of Mutsu Bay. 12. cheilostomatous Bryozoa of Mutsu Bay. Sci. Rep. Tohoku Imp. Univ., Ser. 4, (Biol.), 3(4): 11-35.

Okada. Y. and S.F. Mawatari, 1937. On the collection of Bryozoa along the coast of Onagawa Bay and its vicinity, the northern part of Honshu, Japan. Sci. Rep. Tohoku Imp. Univ., Ser. 4, 11(4): 433-445.

Okada, Y. and S.F. Mawatari, 1938. On the collection of Bryozoa along the coast of Wakayama-ken, the middle part of Honsyu, Japan. Annot. Zool. Jap., 17(3, 4): 445-462.

Osburn, R.C., 1952. Bryozoa of the Pacific coast of America part II, Cheilostomata-Ascophora. Allan Hancock Pac. Exp., 14(2): 271-518.

Pinter, P., 1969. Bryozoan-algal association in southern California waters. Bull. S. Calif. Acad. Sci., 69(4): 199-217.

Powell, N.A., 1967. Polyzoa (Bryozoa)-Ascophora from north New Zealand. Discovery Reports, XXXIV: 199-394.

Rho, B.J. and K.H. Lee, 1980. The marine invertebrate fauna in the Gogunsan Islands and Bian Island, Rep. KACN, (18): 115-124.

Sakakura, K., 1935. Bryozoa from Toyama Bay, Sea of Japan.
Annot. Zool. Jap., 15(1): 106-119, pl. 8.

Seo, J.E., 2005. Illustrated Encyclopedia of Fauna and Flora of Korea Vol. 40 Bryozoa, Ministry of Education and Human Resources Development, pp. 1-596 (in Korean).

Seo, J.E. and Y.H. Gong, 2006. A new species and two new records of Cheilostomata (Bryozoa) from Korea. Korean J. Syst. Zool., 22(1): 13-16.

Seo, J.E. and B.J. Rho, 1989. A systematic study on the marine bryozoans in Korea 6. Ascophora. Korean. J. Syst. Zool., 5(2): 205-223, pls. 1-7.

Sim, J.J. and H.J. Kim, 2002. Taxonomic study on marine sponges from Gageodo Island (Sohuksando), Korea. Korean J. Syst. Zool., 18(2): 219-232.

Soule, J.D., 1961. Results of the Puritan-American Museum of Natural History expedition to western Mexico 13. Ascophoran Cheilostomata (Bryozoa) of the Gulf of California. Am. Mus. Novit., 2053: 1-66.

Soule, J.D. and M.M. Duff, 1957. Fossil Bryozoa from the Pleistocene of southern California. Proc. Calif. Acad. Sci., fourth series, 24(4): 87-146.

Soule, D.F. and J.D. Soule, 1973. Morphology and speciation of Hawaiian and eastern Pacific Smittinidae (Bryozoa, Ectoprocta). Bull. Am. Mus. Nat. Hsit., 152(6): 367-440.

Soule, J.D., D.F. Soule and H.W. Chaney, 1995. Taxonomic atlas of the benthic fauna of the Santa Maria Basin and western Santa Barbara Channel, Volume 13, The Bryozoa. Santa Barbara Mus. Nat. Hist., pp. 1-344.

Suwa, T. and S.F. Mawatari, 1998. Revision of seven species of Microporella (Bryozoa, Cheilostomata) from Hokkaido, Japan, using new taxonomic characters. J. Nat. Hist., 32: 895-922.

Thornely, L.R., 1916. Report on the Polyzoa. Okhamandal Mar. Zool. report, part II: 157-165. 